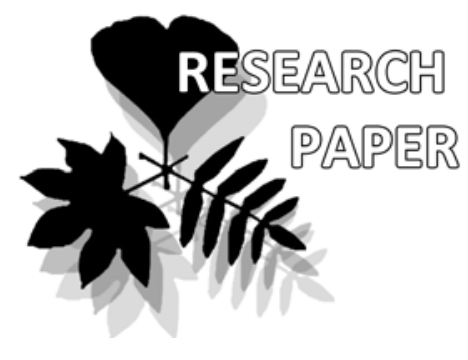

\title{
A revision of Lepidoziaceae (Hepaticae) in the Russian Far East I. Bazzania
}

\author{
Vadim A. Bakalin
}

Vadim A. Bakalin

e-mail: vabakalin@gmail.com

Botanical Garden-Institute FEB RAS, Vladivostok, Russia

Manuscript received: 11.04 .2016 Review completed: 06.05.2016 Accepted for publication: 12.05 .2016 Published online: 13.05.2016

\begin{abstract}
A B S T R A C T
The hepatic genus Bazzania is revised for the Russian Far East. Five species are recognized. Two species (B. bidentula and B. japonica) are excluded from the flora. Two species (B. parabidentula and B. manczurica) are described as new to science. The distribution of taxa in the area is much clarified, with descriptions and illustrations based on studied regional material as well as type specimens. The paper is supplemented by a list of specimens examined (from the Russian Far East and adjacent areas) as well as an identification key to taxa.
\end{abstract}

K e y w o r d s : Lepidoziaceae, Bazzania, taxonomy, Russian Far East, Hepaticae, liverworts

\section{P E 3 Ю M E}

Бакалин В.А. Ревизия Lepidoziaceae (Hepaticae) Аля российского Аальнего Востока I. Bazzania. РоА Bazzania ревизован Аля российского Аальнего Востока. Выявлено 5 вилов. Ава виАа (B. bidentula и B. japonica) исключены из состава флоры. Ава виАа (B. parabidentula и B. manczurica) описаны как новые Аля науки. Распространение видов в преде ах изученного региона существенно уточнено. Составлены описания и илАюстрации по изученным региональным материалам и типовым образцам. Статья вкАючает список изученных образцов (из российского Аальнего Востока и прилегающих регионов) и кАюч Аля определения виАов, признаваемых на этой территории.

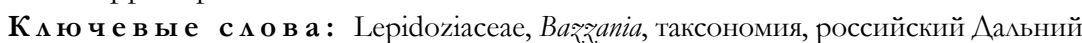
Восток, Нераticae, печеночники

\section{N T ROD U C T IO N}

Lepidoziaceae are most taxonomically diverse in the South Temperate Zone, Neotropics and, to a lesser extent, in the Paleotropics. The number of genera and species is difficult to estimate; according to Frye (2009) ca. 440 species of 29 genera actually exist, although the number of genera may be increased through future research (cf. Crandall-Stotler et al. 2009). Nevertheless, Russian Far East Lepidoziaceae is quite limited in number of taxa, and includes five species of Bazzania (three do not occur in any other part of Russia), two species of Lepidozia (one limited in Russia by southernmost flank of the Far East) and one species of Kurzia (which does not occur in Russia outside of the Far East). A major advance in the study of Lepidoziaceae in the Russian Far East was the paper by Zerov (1966), "Lepidoziaceae of the Soviet Far East". This paper provides morphological descriptions for all then-known taxa from the area, including Bazzania tricrenata, B. bidentula, and B. japonica as new records for the Far East (the two latter ones also were new for the USSR). The work by Zerov (1966) was based on rather limited number of specimens, thus distribution of the taxa is quite out of data now. Besides, two other problems exist: that work did not include study of type specimen (which resulted in a probable mis-recording of Bazzania japonica for the Far East), nor does the paper provide identification keys. Thus the paper by Zerov (1966) could not be used for identification of the species.

In the course of recent research in the Russian Far East, many new specimens from remote, uninvestigated areas were collected, as well as a lot of other new data on species distribution were obtained. In addition, I was able to study type specimens for some East Asian taxa that clarified the treatment of the taxa. These advances contributed to a new revision of this group for the area. This is also urgent in the view of the continuing preparation of a new manual for Russian Far East hepatics. This study will appear in two parts, the first one a treatment of Bazzania and the second a general treatment the family and description of the remaining genera.

\section{TAXONOMIC TREATMENT}

Bazzania Gray Nat. Arr. Brit. Pl. 1: 704, 1821.

Description. Plants prostrate to ascending, rarely erect, in dense to loose patches, deep green to greenish yellowish and brownish, strongly varying in size (from 0.7 to $5.5 \mathrm{~mm}$ in regional taxa), freely pseudodichotomously terminally (Frullania-type) branched for normal branches, and also 
commonly with numerous ventral intercalary flagellae. Rhizoids virtually absent or scarce, present as short erect-spreading fascicles originated near ventral underleaf base. Leaves incubous, 1-4-lobed, sometimes with additional teeth along margin (mostly confined to apical third of the leaf), incubously obliquely inserted, slightly to strongly convex, in some taxa strongly curved to ventral side, easily deciduous in some taxa. Underleaves appressed to the stem or obliquely to erect-spreading, plane to recurved along margin, with apex commonly lobed or coarsely crenulate and dentate, rarely almost entire, chlorophyllose or hyaline along margin. Midleaf cells mostly pachydermous, rarely leptodermous; cuticle smooth to (rarely) papillose; oil bodies mostly smooth surfaced, botryoidal, rarer homogenous to homogenous biconcentric, or ellipsoidal and having finely granulate surface. Dioicous (commonly sterile), with archegonia and androecia appearing on short ventral intercalary branches. Male bracts spicate, in 4-6 pairs, ovate, cupped, entire to bilobed, 1-2-androus. Female bracts ovate, similar in shape and size to bracteoles, imbricate. Perianth long-conical to fusiform, commonly with three main plicae; perigynium absent. Sporophyte (not known in treated area) with robust seta of ca. 16 epidermal and numerous internal rows; capsule ovoid to oblong-ovoid, capsule wall 4-6-stratose; elaters bispiral; spores small, brown (Schuster 1969).

Comment. Among regional taxa the genus is very easily identified and is not likely to be mistaken for others. I expect that confusion is only possible with Metacalypogeia cordifolia (Steph.) Inoue, which is characterized, like some Bazzania, by sometimes shortly lobed leaves (at least some phases), and dark green plant color. However, Bazzania is easily distinguished even in sterile and old material by the common presence of ventral scale-like leaved branches (= ventral flagellae), underleaves in apical part crispate to distinctly divided into acute lobes, while this kind on stolons are absent and underleaves entire to emarginate with universally entire margin. Additionally Metacalypogeia has evenly distributed rhizoids, versus rhizoids virtually absent or confined to underleaf bases in Bazzania.

\section{Key to Bazzania distributed in the Russian Far East}

1. Leaves generally bilobed, rarely (poorly developed) unlobed, never (or as solitary exception) trilobed ... 2

1. Well developed leaves trilobed, on weak plants sometimes bilobed or unlobed, but with always evident admixture of trilobed leaves

2. Oil bodies distinctly biconcentric or botryoidal, smoothsurfaced, nonbiconcentric, plants brownish to brown, leaves hardly deciduous, obligate epilithic ..... B. manczurica

2. Oil bodies homogenous, ellipsoidal, plants green to brownish green, leaves easily deciduous, mostly epixylous ......... 3

3. Plants brownish, leaf cuticle strongly and distinctly papillose [south to south-east China, subtropical East Asian] ....... [B. bidentula $]$

3. Plants greenish, leaf cuticle smooth [oro-boreo-temperate Asian] B. parabidentula

4. Plants brownish to brown, rarely (from very shady habitats) green, leaves when wet distinctly and strongly recurved to ventral side

4. Plants green to deep green, rarely pale brownish green, leaves, when wet, slightly convex, not or loosely recurved to ventral side

5. Oil bodies nonbiconcentric, finely granulate

[B. imbricata, see comment under B. tricrenata]

5. Oil bodies smooth, segmented into 2-4 connate spherules nonbiconcentric or (in our area only following variant) distinctly biconcentric B. tricrenata

6. Leaves in upper $1 / 2$ of its length with margin arcuate, underleaves crispate to divided into several obtuse lobes, never sharply dentate

B. denudata

6 . Leaves in upper $1 / 3-1 / 2$ of its length with margin nearly straight (commonly subparallel one to another), underleaves always distinctly lobed, lobes acute, their margins entire to sharply dentate

7. Underleaves 3-5-lobed, sharply dentate and sometimes discolored at narrow band along margin, plants mostly over $3.5 \mathrm{~mm}$ wide

B. trilobata

7. Underleaves with acute, although sometimes short lobes, underleaf margin not discolored, plants mostly less than $3.5 \mathrm{~mm}$ wide

[B. japonica]

[Bazzania bidentula (Steph.) W.E. Nicholson in Horik.] J. Sci. Hiroshima Univ. Ser. B., Div. 2, 2: 192. 1934. Basionym: Pleuroschisma bidentulum Steph. Mém. Soc. Sci. Nat. Math. Cherbourg 29: 222. 1894. (G-00264760!) Holotype: China, Yunnan, leg. 15.VIII.1885, Delavay 484, (probable correct spelling of locality from label: "Col de Lopin-Chan au dessus de Lan-Kong").

Description. Plants slender, mostly prostrate, greenish brownish, 20-30 or more mm long and 1000-1600 $\mu \mathrm{m}$ wide with numerous ventral flagella that very rarely (one branch seen) become normal branches, leaves easily deciduous such that about 30-50\% of the plant length (aside flagellae) is defoliated (sometimes also 'deamphigastriated'). Stem slightly transversely elliptic in the cross section, ca. $200 \times 230 \mu \mathrm{m}$, external wall strongly thickened, outer layer with thickened walls and large, triangular to convex trigones, inward cell walls thin, trigones moderate in size and concave. Rhizoids virtually absent, rarely present on the flagellae, then sparse, colorless, obliquely spreading, united into unclear fascicles. Leaves incubously obliquely to subhorizontally inserted, erect-spreading, subhorizontally oriented, slightly convex and turned to ventral side of the stem (both in dry and wet condition), distant, obliquely ovate to loosely falcate, $550-800 \times 250-400 \mu \mathrm{m}$, shortly bilobed by U-shaped sinus (well-developed lobes commonly acute, $3-5$ cells long and $2-3$ cells wide, weak lobes may be reduced to one-celled prominent tooth) or unlobed with acute apex. Underleaves nearly plane, obliquely to erectspreading, $200-250 \times 220-260 \mu \mathrm{m}$, lingulate, with crispate (never distinctly lobed) apex, free or connate with one leaf of corresponding leaf pair. Midleaf cells subisodiametric to shortly oblong, $21.0-31.0 \times 14.5-22.4 \mu \mathrm{m}$, thin-walled, trigones moderate in size to large, convex, cuticle distinctly papillose; cells along margin 10-16 $\mu \mathrm{m}$, thin-walled, but with strongly thickened external wall, papillose-verrucose, trigones large, convex; cells in leaf apices with papilloseverrucose cuticle and large convex trigones. (Fig. 1: 10-18)

Comment: Bazzania bidentula has been often recorded for the Russian Far east and adjacent areas (like Korean Peninsula and northern Japan). However, after study of type material in G I found all of those records may be based on 


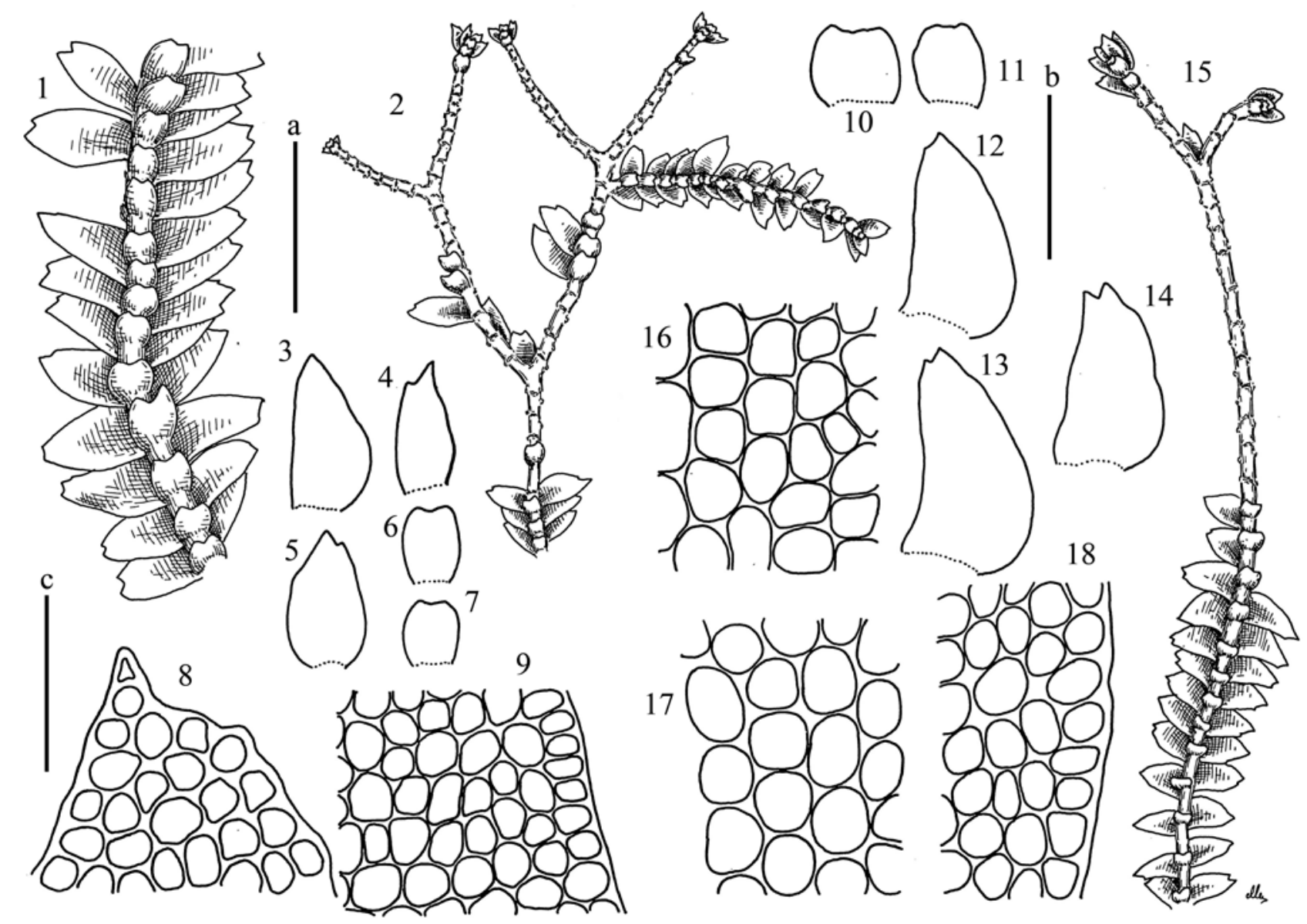

Figure 1 Bazzania parabidentula Bakalin: 1,2 - plant habit, ventral view; 3-5-leaves; 6, 7 - underleaves; 8 - leaf apex; 9 - leaf margin (from p-72-8-11, VBGI). Bazzania bidentula (Steph.) W.E. Nicholson: 10, 11 - underleaves; 12-14 - leaves; 15 - plant habit, ventral view; 16, 17 midleaf cells; 18 - cells along leaf margin (from holotype of Pleuroschisma bidentulum Steph., G-00264760). Scales: a $-1 \mathrm{~mm}$, for 2, 15; a - 500 $\mu$ m, for 1 ; $\mathrm{b}-500 \mu \mathrm{m}$, for $3-7,10-14$; $\mathrm{c}-100 \mu \mathrm{m}$, for $8,9,16-18$

misidentifications due to a misunderstanding of B. bidentula. This taxon (described from subtropical Chinese Yunnan, far from the Russian Far East), as I could see from type specimen (G-00264760) is characterized by the following features unlike those of the Russian Far East species: 1) brownish color of plants, 2) leaves evidently turned to dorsal side, 3) apparent epilithic occurrence, and especially 4) coarsely and throughout papillose to verrucose (near margins) leaf cuticle. These morphological traits as well as the phytogeographic distance between $B$. bidentula in China and the Russian Far East and Korean Peninsula (B. bidentula s. str. is not known north-eastward of the line Shaanxi Hubei - Taiwan, cf. Piippo 1990) support the concept that in our area we have another, as yet undescribed taxon, that I present below under the name B. parabidentula. Although I think the occurrence of true B. bidentula in the Russian Far East (as well as in adjacent areas) is hardly possible, I provided above the morphological description and figures of the species based on type specimen.

\section{Bazzania parabidentula Bakalin sp. nov.}

Description. Plants 10-25 mm long, 700-1000 $\mu \mathrm{m}$ wide, forming loose patches, fragile, pale greenish to yellowish green, pale brownish green in the herbarium. Stem $50-125 \mu \mathrm{m}$ in diameter, freely branched, without numerous ventral flagellae. Rhizoids virtually absent. Leaves contigu- ous to distant or (rarely) subimbricate, dorsal insertion line oblique, not turned to ventral side, loosely ob-canaliculate, very easily caducous, obliquely ovate, commonly bilobed, rarer unlobed or (as exception) trilobed, 300-450 × 150 $225 \mu \mathrm{m}$, mostly narrower and only slightly longer than underleaves. Underleaves caducous, but not falling so easily as leaves, obliquely spreading, not recurved, mostly longer than wide, spatulate to narrowly obtrapezoidal, not of barely connate with one leaf of the pair, apex crispate or more or less distinctly 2-3-lobed with rounded lobes. Midleaf cells $17-25 \times 15-24 \mu \mathrm{m}$, thin-walled, trigones moderate in size, slightly convex to slightly concave, cuticle smooth; cells along margin 7-15 $\mu \mathrm{m}$, more or less thin-walled, external wall thickened, with moderate to large, slightly convex to slightly concave trigones, cuticle smooth; cuticle in leaf apex smooth; oil bodies homogenous, shortly oblong to irregularly elongated, rarely loosely segmented. (Fig. 1: 1-9; 2)

Holotype: RUSSIA. Primorsky Territory, Lazovsky Pass $\left(43^{\circ} 29^{\prime} 38^{\prime \prime} \mathrm{N} 133^{\circ} 34^{\prime} 45^{\prime \prime E}\right), 915 \mathrm{~m}$ alt., $915 \mathrm{~m}$ alt., decaying wood in part shade. Leg. V.A. Bakalin, 22 Sept. 2011, P-72-8-11 (VBGI).

Ecology. This species is almost obligate epixylous, occupying merely shaded decaying wood in coniferous oroboreal (much rarer boreal lowland) to broadleaved temperate forests. However, there are a few exceptions, as when B. parabidentula was found in other habitats such as, for instance, 
moss carpet in cliff crevice near sea coast in more or less open site. The latter may be explained by specific combination of climatic features (especially high humidity) and lowered competition. A related habitat was found in Korea: on lower branches of living Thuja koreana. Only once it was found growing over stones in Betula ermanii forest. The majority of other records of this species from nonwoody habitats should be referred to other species (mostly to B. manczurica).

Distribution. The species may be regarded as a more or less distinct remnant of the ancient Ginkgo flora formation (see Popov 1983 and also Bakalin 2014). It occurs in the southern flank of the Russian Far East in Primorsky Territory (where it is the most common), widely spreading westward as far as Baikal Lake (not rare in Khamar-Daban Range, but very sparse in other part of South and southern part of East Siberia). Bazzania parabidentula reaches southern tips of Korean Peninsula (where, however much rarer than in Primorsky Territory of Russia), and expected as merely common in northern half of Japan, where is occurs starting in middle Honshu only in higher elevations (oroboreal and hemiboreal coniferous forest belt).

Differentiation. The species may be easily mistaken with $B$. denudata that produces in harsh habitats (most probable reasons are too dry or too sunny substrata) small forms with very easily deciduous leaves, small, bilobed leaves, and a few ventral flagellae. These forms sometimes may be clearly different from $B$. parabidentula, but in most cases the following features are reliable: 1 ) leaves ob-canaliculate, not turned to ventral side when wet in B. parabidentu$l a$, versus leaves convex, distinctly turned to ventral side in B. denudata; 2) well-developed leaves (present at least in the bases of some shoots) are obliquely ovate with truncate and trilobed apex in B. denudata, versus leaves bilobed (trilobed as exception), with gradually narrowed acute bilobed or unlobed apex in B. parabidentula. The differentiation of this species from $B$. bidentula (which seems to be absent in the Russian Far East) is discussed under the latter.

Bazzania denudata (Torr. ex Gottsche, Lindenb. \& Nees) Trevis., Mem. Reale Ist. Lombardo Sci., Ser. 3, Cl. Sci. Mat. 4: 414, 1877 (= Bazzania denudata subsp. ovifolia (Steph.) S. Hatt., J. Hattori Bot. Lab. 18: 82, 1957; Bazrania ovifolia (Steph.) S. Hatt. J. Jap. Bot., 19: 347, 1943.

Description. Plants deep green to brownish green, yellowish green and brownish green, 15-40 mm long, 1000$2500 \mu \mathrm{m}$ wide, more or less rigid, forming loose patches. Stem $200-450 \mu \mathrm{m}$ in diameter, easily branched, with numerous or a few (forms with caducous leaves) ventral flagellae. Rhizoids virtually absent, rarely a few, in erect fascicles originated near underleaf bases. Leaves mostly contiguous, but also subimbricate or distant, not or easily deciduous, convex, turned to dorsal side when wet, dorsally insertion line oblique to subtransverse or loosely arcuate, ventrally leaf connate with underleaf or not connate, obliquely ovate, distinctly trilobed with lobes more or less acute lobes or (1-)2-3-lobed with lobes obtuse, leaf margin entire to loosely crispate, $700-1250 \times 500-880 \mu \mathrm{m}$. Underleaves connate with both or with one leaf of the pair or (rarer) not connate, transversely elliptic, erect-spreading, plane or recurved, 3-5-lobed or crispate, lobes (if present) obtuse to rounded at apices. Midleaf cells 20-32 × 20-27 $\mu \mathrm{m}$, thinwalled, trigones moderate in size, convex, cuticle smooth; lobe apices with smooth cuticle; cells along leaf margin 20 $25 \mu \mathrm{m}$, more or less thin-walled, with large, slightly convex trigones, external wall noticeable to moderately thickened, cuticle smooth; oil bodies homogenous, spherical to oblong and shortly fusiform, occasionally segmented. (Fig. 3, 4, 5: 1-8; 7: G-I)

Ecology. An acidophilic mesophyte, Bazzania denudata occupies various types of habitats: decaying wood, humus on steep slopes, cliff crevices, and avoids dry substrata. It prefers merely shaded habitats, rarely occurring in open sites or in full shade. In elevation B. ovifolia starts from low level of hemiboreal and cold temperate zones and attains the subalpine (exceptionally rare alpine) belt in mountains in southern part of the Russian Far East. It rarely occurs in the crevices of partly shaded coastal cliffs with heathland vegetation (although surrounded by oak forest with Lespedeza cover) under severe wind regime. The species is relatively more plastic ecologically and sometimes occurs with other taxa of the genus, like B. tricrenata (in cliffs) and B. bidentula (on decaying wood). On the forest floor the species sometimes grows together with B. trilobata.

Distribution. This is the most common species of the genus in the southern flank of the Russian Far East (the same with northern Japan and Korean Peninsula). The general distribution of the species is boreo-temperate East Asian-American. In the New World it is known from Alaska, British Columbia, Washington and Alberta, continuing westward to Atlantic coast (being much more frequent in coastal areas, although also occurring in interior states). In East Asia this species is the most frequent taxon of the genus in South Kurils, Hokkaido and Manchuria, where it occurs from near to seal level and up to $1800 \mathrm{~m}$ a.s.l. Northward of $45-48^{\circ} \mathrm{N}$ the species becomes noticeably rare, although known in isolated localities in $59^{\circ} \mathrm{N}$ (Magadan) and $54^{\circ} \mathrm{N}$ (West Kamchatka) belonging to the Hemiarctic. The first of the above mentioned records is from mesophytic coastal Alnus crooked forest and the second one is from Betula ermanii 'crooked' forest replacing northern boreal coniferous forest in suboceanic Hemiarctic. These occurrences may be regarded as having a relict nature (cf. Bakalin 2009). Southward the species' habitat becomes mountainous, and the species is completely replaced in formally suitable habitats in low elevations of southern half of Honshu, as well as Shikoku and Kyushu (in my experience) by two related taxa: B. tridens and B. japonica, of somewhat similar habits.

Comment. The degree of variability of $B$. denudata is controversial. The type of the species is from New York State of U.S.A. Hattori \& Mizutani (1958), follow by Schuster (1969), treated plants from East Asia as a distinct subspecies (ssp. ovifolia). Soviet and Russian research (starting most probably from Zerov 1962) regarded it as distinct species. This point of view was followed in recent checklist and maps for the Russia (Konstantinova et al. 2009, Bakalin 2010). Contrarily, Yamada \& Iwatsuki (2006), as well as many recent local floristic lists in Japan, treat B. ovifolia as a synonym of $B$. denudata. Recently I was able to study types 


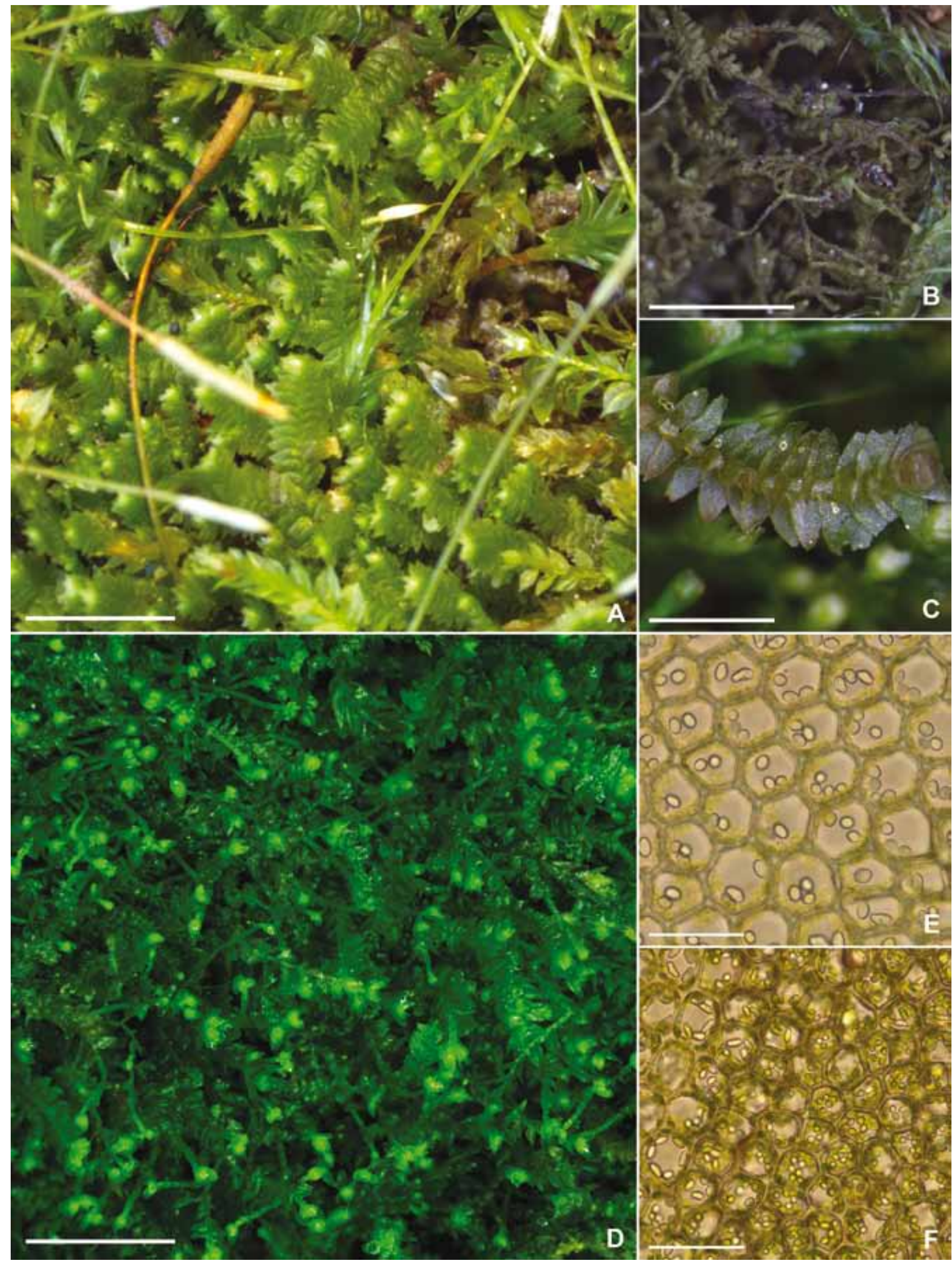

Figure 2 Bazzania parabidentula:A - habit, from p-72-8-11; B - Habit, dry condition in the herbarium (from p-72-8-11, VBGI); C - habit, ventral view (from j-88-60-15, VBGI); D - plant habit, from p-39-20-14; E - oil bodies in the midleaf cells, from j-88-21-15; F - oil bodies in the midleaf cells, from j-88-60-15. Scales: A $-2 \mathrm{~mm}, \mathrm{~B}-2 \mathrm{~mm}, \mathrm{C}-1 \mathrm{~mm}, \mathrm{D}-2 \mathrm{~mm}, \mathrm{E}-50 \mu \mathrm{m}, \mathrm{F}-50 \mu \mathrm{m}$ 


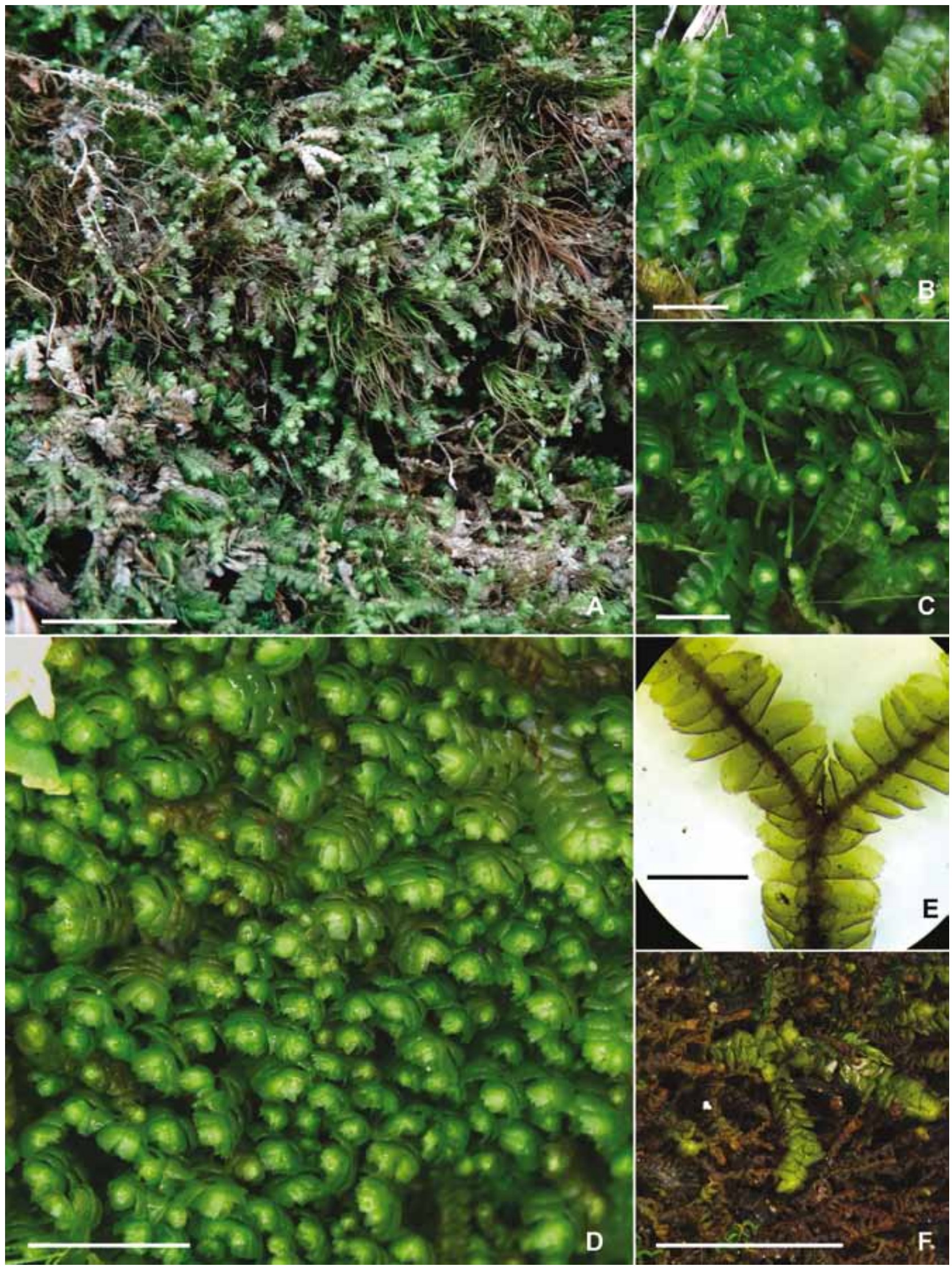

Figure 3 Bazzania denudata: A - habit in natural conditions; B - habit (from k-70-51-15, VBGI); C - habit (from p-37-36a-14, VBGI); D - habit (from p-35-28-14, VBGI); E - habit, ventral view, from holotype; F - habit (mixed with B. manczurica), dry plants in the herbarium (from p-37-3614, VBGI). Scales: A $-10 \mathrm{~mm}, \mathrm{~B}-2 \mathrm{~mm}, \mathrm{C}-2 \mathrm{~mm}, \mathrm{D}-5 \mathrm{~mm}, \mathrm{E}-2 \mathrm{~mm}, \mathrm{~F}-5 \mathrm{~mm}$ 


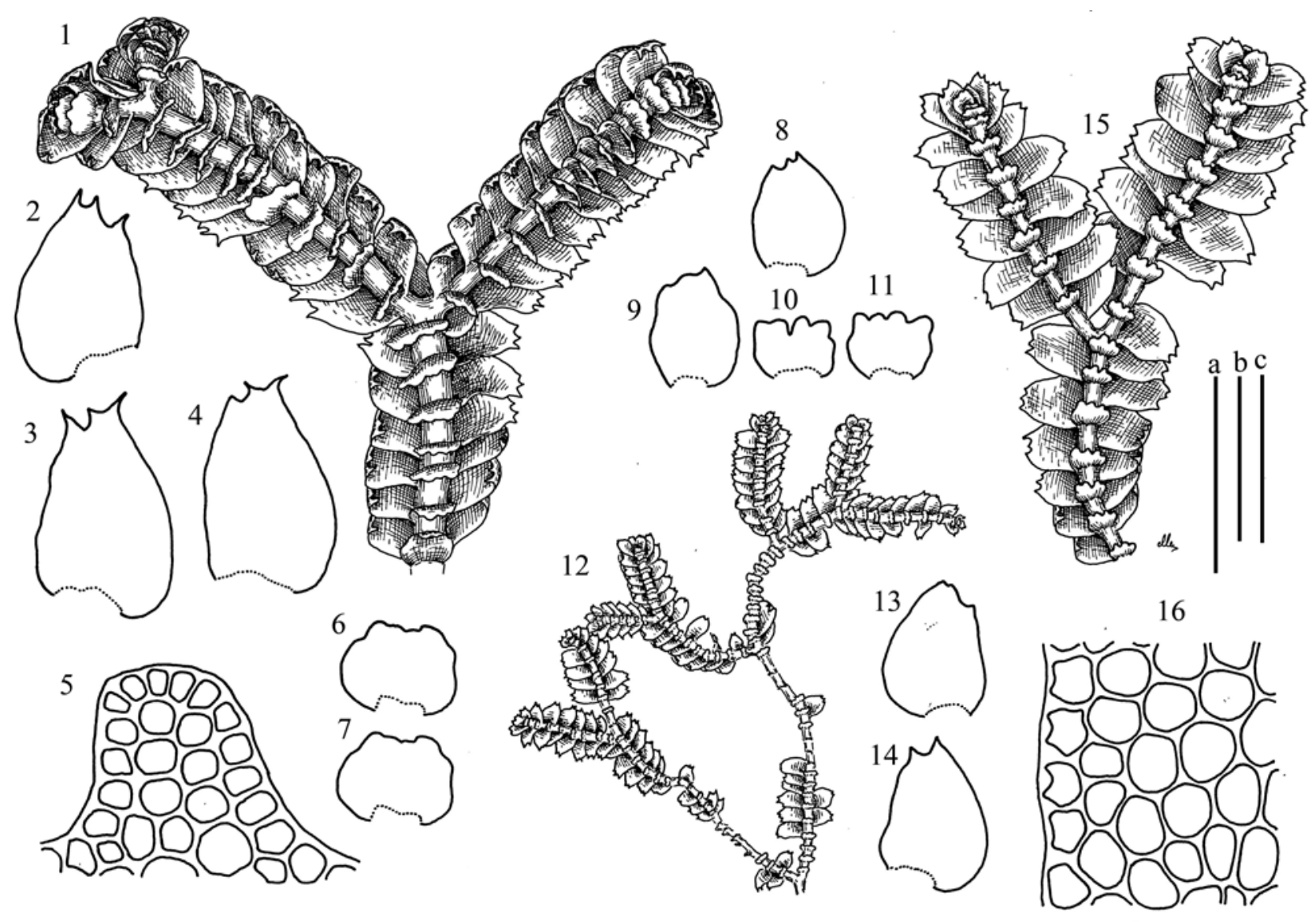

Figure 4 Bazzania denudata (Torr. ex Gottsche, Lindenb. \& Nees) Trevis.: 1, 12, 15 - plant habit, ventral view; 2-4, 8, 9, 13, 14 - leaves; 5- underleaf lobe, magnified; 6, 7, 10, 11 - underleaves; 16 - cells along leaf margin (1-7 - from p-79-3-07, VBGI; 8-16 - from p-44-51-10, VBGI). Scales: $\mathrm{a}-2 \mathrm{~mm}$, for 1,$15 ; \mathrm{a}-5 \mathrm{~mm}$, for $15 ; \mathrm{b}-1 \mathrm{~mm}$, for $2-7,8-12,14 ; \mathrm{c}-100 \mu \mathrm{m}$, for 5,16

of both species and found they contain the plants that were indeed different (as noted by Schuster, cited by Hattori \& Mizutani 1958) in dentation of leaf apical portion. However, when a large amount of material is under consideration, these features are not stable and dentation of the leaf apex is the subject of the great variation within the same area, thus no morphological features that may distinguish the two taxa were I able to find. Moreover, before the treatment of Bazzania for Japan by Hattori and Mizutani, nothing was known of the distribution of ' $B$. ovifolia' northward of Japan that allowed plants from Japan to be treated as a geographic subspecies. On the contrary, now B. denudata is known up to $59^{\circ} \mathrm{N}$ and therefore there are no longer any geographically valuable gaps. Therefore I think now it is better to follow Yamada \& Iwatsuki (2006) and to treat $B$. denudata as a single taxon with East Asian - American Range.

\section{Bazzania manczurica Bakalin sp. nov.}

Description. Plants prostrate, more or less rigid and fragile, brown to green-brown, sometimes with rusty or reddish tint, 15-25 mm long, 870-1650 $\mu \mathrm{m}$ wide, forming loose patches. Stem easily branched, $125-200 \mu \mathrm{m}$ in diameter, ventral flagellae present, but not frequent. Rhizoids virtually absent. Leaves not or barely caducous, nearly plane or slightly convex, not turned to dorsal side, ventrally not or barely (seems to be only juxtaposed) connate, obliquely ovate, (1-)2(-3)-lobed, with V- to U-shaped sinus, 600-950 $\times 350-550 \mu \mathrm{m}$, contiguous or (more commonly) distant. Underleaves transversely elliptic to lingulate and widely lingulate, mostly not connate with leaves, crispate or shortly 2-3-lobed in apex, lobes (if present) rounded to semicrescentic, $150-250 \times 225-275 \mu \mathrm{m}$, obliquely spreading, not recurved. Midleaf cells $15-25 \times 15-20 \mu \mathrm{m}$, walls brownish, thin, trigones moderate, concave to triangular, cuticle smooth; cells along margin 10-13 $\mu \mathrm{m}$, thin-walled, external wall thickened, trigones moderate in size to large, concave to slightly convex, cuticle smooth; cuticle in lobe apices smooth; oil bodies smooth-surfaced to loosely granulate, spherical to oblong and fusiform, almost invariable biconcentric (having one pupil) (Fig 5: 9-20; 6: 1, 2; 7: A-F).

Holotype: Russia. Primorsky Territory, Partizansky District, SW-facing slope of Olkhovaya Mt $\left(43^{\circ} 20^{\prime} 42^{\prime \prime N}\right.$ $\left.133^{\circ} 40^{\prime} 26^{\prime \prime E}\right), 1200 \mathrm{~m}$ alt., mixed Manchurian hemiboreal forest, mesic cliffs, in part shade. Leg. V.A. Bakalin 13 Sept. 2014, P-36-11-14 (VBGI).

Ecology. An acidophilic mesophyte, Bazzania manczurica seems to be generally an epilithic taxon, rarely occurring, however, on decaying wood. It prefers more or less vertical and partly shaded mesic and acidic cliffs (rather than boulders) and is limited in distribution mostly to Manchurian ecosystems, including hemiboreal mixed forests, although also ascending to mountains (not far from contact zone with hemiboreal) or descending to broadleaved cool oro- 

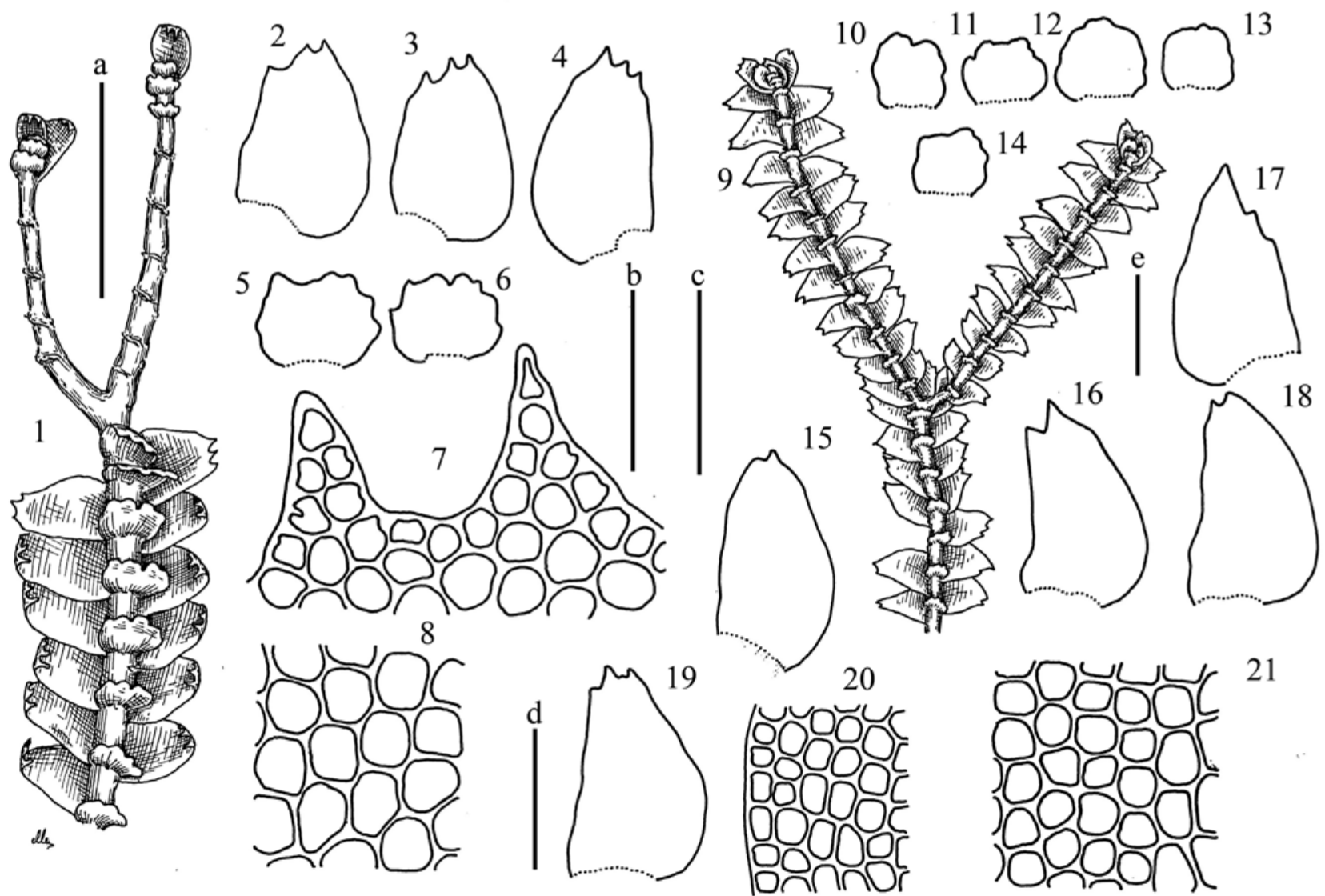

Figure 5 Bazzania denudata (Torr. ex Gottsche, Lindenb. \& Nees) Trevis.: 1 - plant habit, ventral view; 2-4 - leaves; 5, 6-underleaves; 7 - leaf apex; 8 - midleaf cells (1 - from holotype, STR; 2-8 - from holotype of Mastigobryum ovifolium Steph., G). Bazzania manczurica Bakalin: 9 - plant habit, ventral view; 10-14 - underleaves; 15-19- leaves; 20 - cells along leaf margin; 21 - midleaf cells (from p-36-11-15, VBGI). Scales: a - 2 mm, for $1 ; \mathrm{b}-1 \mathrm{~mm}$, for $2-6 ; \mathrm{c}-100 \mu \mathrm{m}$, for $7,8,20,21 ; \mathrm{d}-500 \mu \mathrm{m}$, for $10-19$; e $-1 \mathrm{~mm}$, for 9
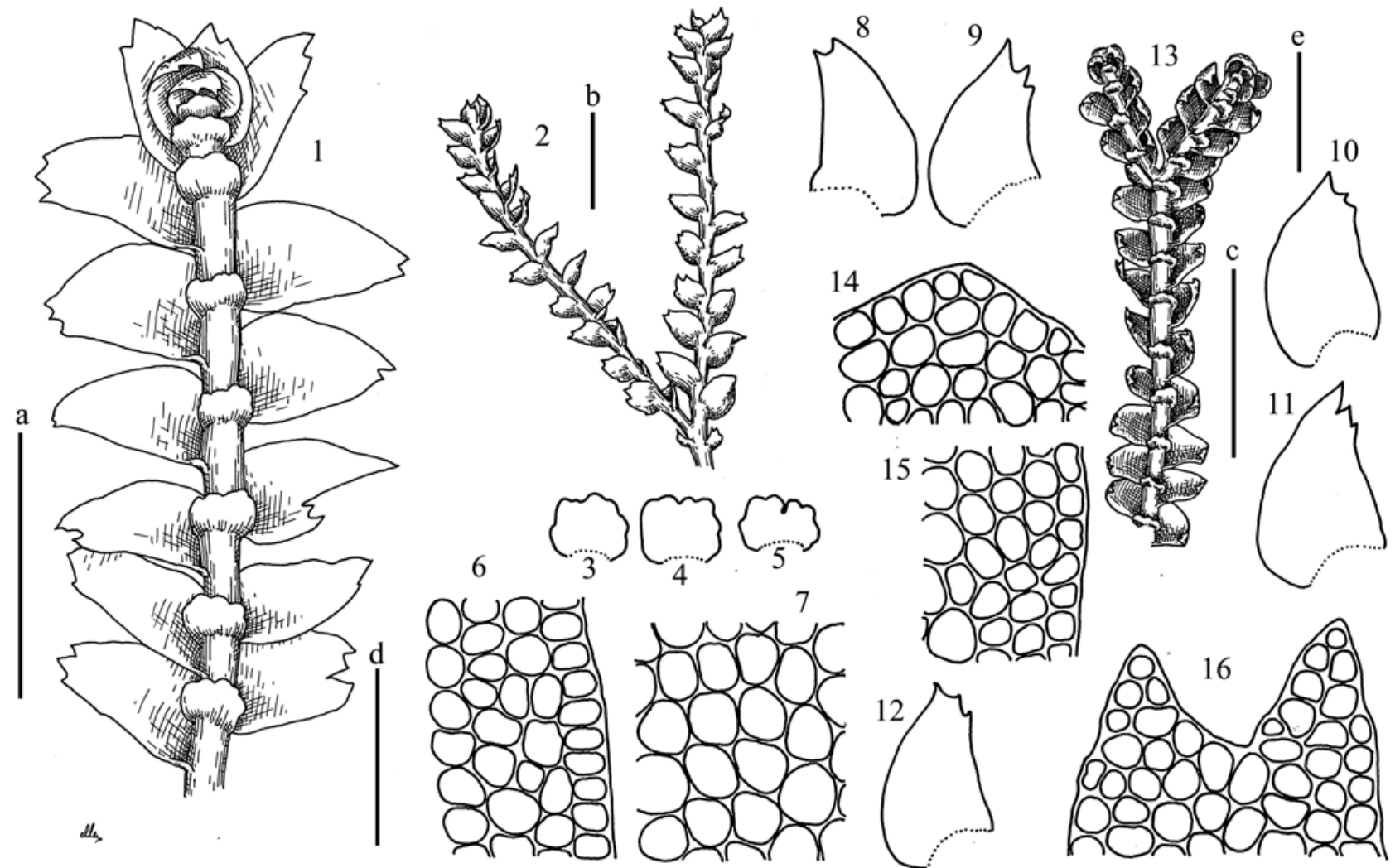

Figure 6 Bazzania manczurica Bakalin: 1 - plant habit, ventral view; 2 - plant habit, dorsal view (1 - from p-36-11-15; 2 - from kor-10-11-11, VBGI). Bazzania tricrenata (Wahlenb.) Trevis.: 3-5 - underleaves; 6, 15 - cells along leaf margin; 7 - midleaf cells; 8-12 - leaves; 13 - plant habit, ventral view; 14, 16 - leaf lobes (1-13 - from p-79-6-07, VBGI; $14-16$ - from p-39-2-14, VBGI). Scales: a - $1 \mathrm{~mm}$, for 1, b - $1 \mathrm{~mm}$, for 2; c - 1 $\mathrm{mm}$, for 3-5, 8-12; d-100 $\mu \mathrm{m}$, for $6,7,14,16$; e $-1 \mathrm{~mm}$, for 13 


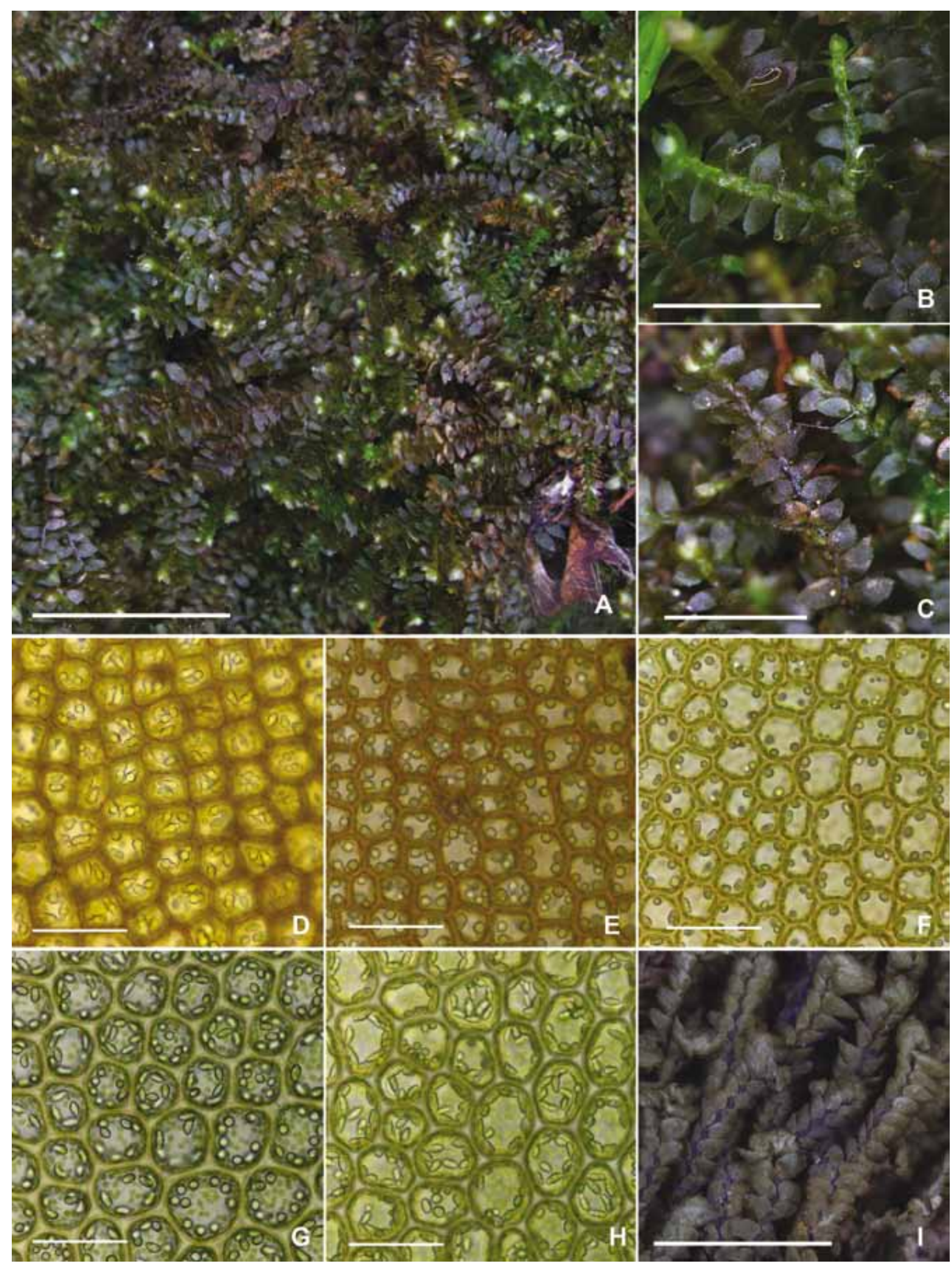

Figure 7 Bazzania manczurica Bakalin: A - habit, from p-36-11-14; B - habit (from p-37-36-14, VBGI); C - habit (from p-36-11-14, VBGI); D - oil bodies in the midleaf cells (from kor-16-16-15, VBGI); E - oil bodies in the midleaf cells (from p-36-11-14, VBGI); F - oil bodies in the midleaf cells (from p-37-36-14, VBGI). Bazzania denudata: $\mathrm{G}$ - oil bodies in the midleaf cells, from p-35-28-14; H - oil bodies in the midleaf cells, from p-37-36a-14; I - habit, in dry conditions from herbarium (from p-18-12-12, VBGI). Scales: A - $5 \mathrm{~mm}, \mathrm{~B}-2 \mathrm{~mm}, \mathrm{C}-2 \mathrm{~mm}, \mathrm{D}-50$ $\mu \mathrm{m}, \mathrm{E}-50 \mu \mathrm{m}, \mathrm{F}-50 \mu \mathrm{m}, \mathrm{G}-50 \mu \mathrm{m}, \mathrm{H}-50 \mu \mathrm{m}, \mathrm{I}-5 \mathrm{~mm}$ 


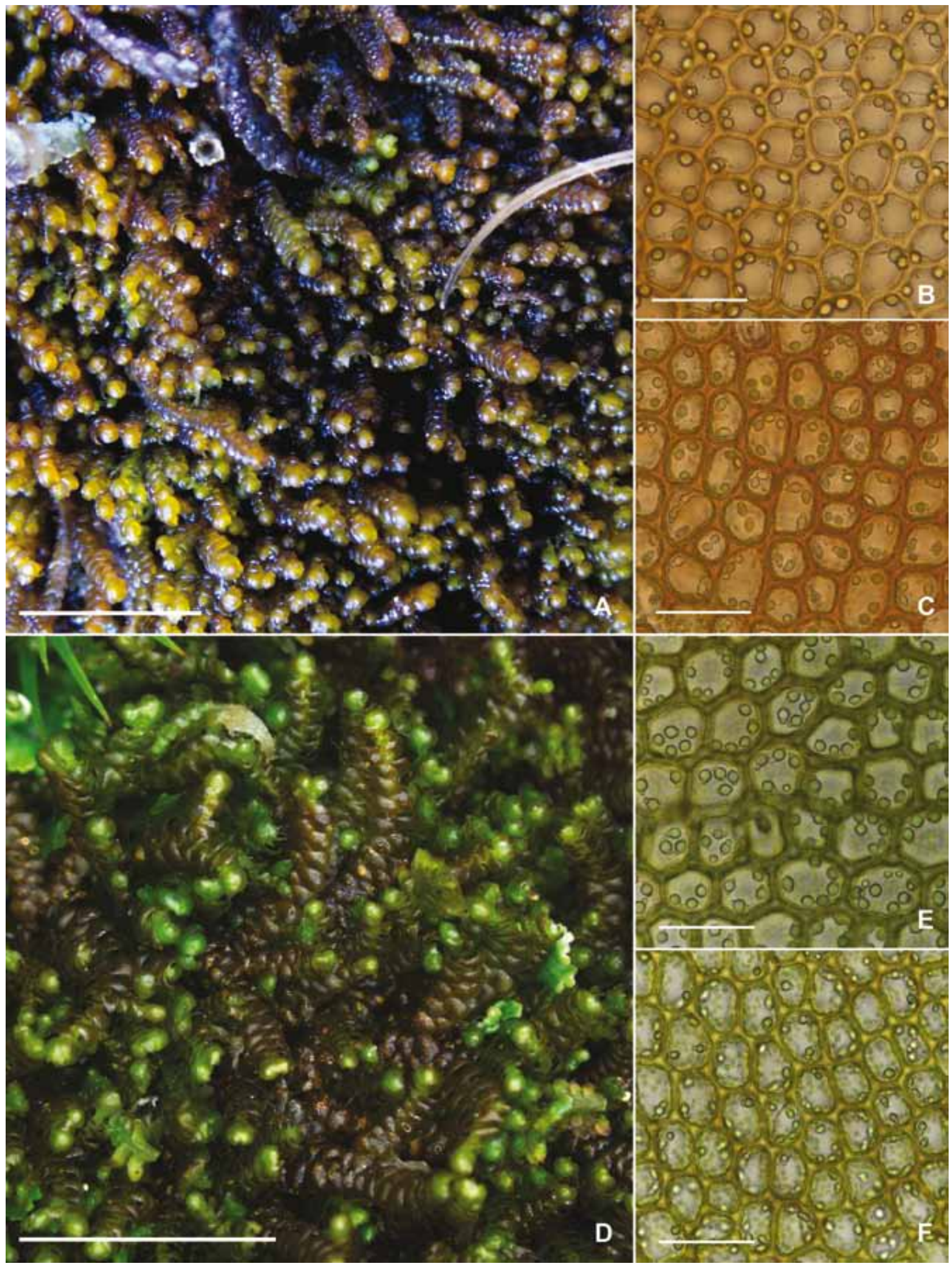

Figure 8 Bazzania tricrenata A - habit, from nature conditions, Yamanashi Pref., Japan; B - oil bodies in the midleaf cells (from j-86-1-15, VBGI); C - oil bodies in the midleaf cells, from j-90-10-15; D - plant habit (from p-39-2-14, VBGI); E - oil bodies in the midleaf cells, from $\mathrm{p}-37-5-14 ; \mathrm{F}$ - oil bodies in the midleaf cells (from p-39-2-14, VBGI). Scales: A - $5 \mathrm{~mm}, \mathrm{~B}-50 \mu \mathrm{m}, \mathrm{C}-50 \mu \mathrm{m}, \mathrm{D}-5 \mathrm{~mm}, \mathrm{E}-50 \mu \mathrm{m}, \mathrm{F}-50 \mu \mathrm{m}$. 


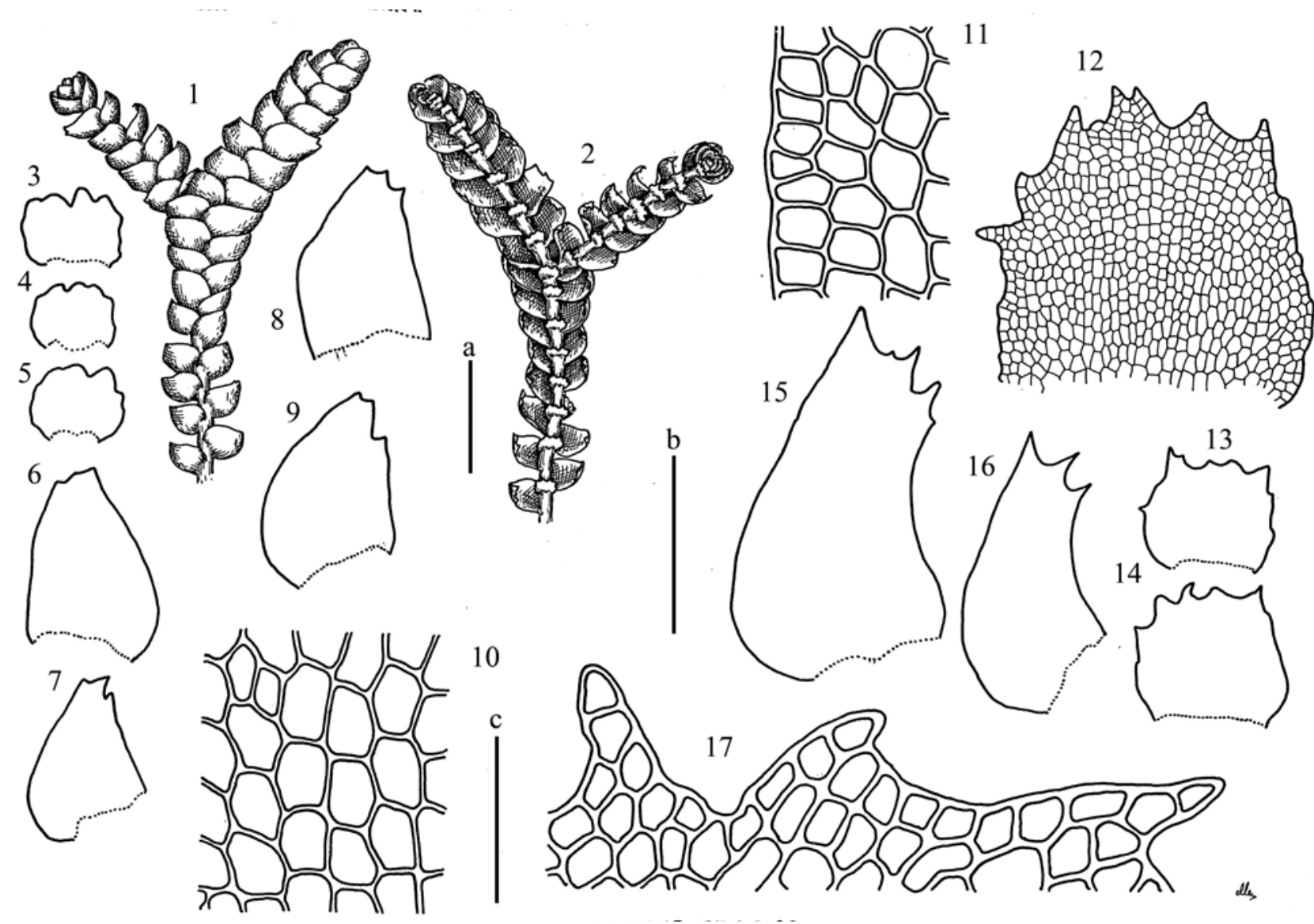

Figure 9 Bazzania tricrenata (Wahlenb.) Trevis.: 1 - plant habit, dorsal view; 2 - plant habit, ventral view; 3-5 - underleaves; 6-9 - leaves (from p-39-2-14, VBGI). Bazzania japonica (Sande Lac.) Lindb.: 10 - midleaf cells; 2 - cells along leaf margin; 12-14 - underleaves; 15, 16 - leaves; 17 - underleaf apex (from j-40-148-14, VBGI). Scales: a $1 \mathrm{~mm}$, for 1, 2; b - $1 \mathrm{~mm}$, for 3-9, 13-16; c - $100 \mu \mathrm{m}$, for 10, 11, 17; c - 400 $\mu \mathrm{m}$, for 12

temperate communities southward (in Korean Peninsula).

Distribution. The distribution of the taxon seems to be broadly Manchurian, with a few localities outside. It seems to be not rare in southern half of Primorsky Territory and mountainous areas of Korean Peninsula (with the exception of southern tips of the latter). Isolated populations are known (probably more widely distributed) in northern Japan and Central Sakhalin, as well as stretching area westward to Lake Baikal, and likely may be found other areas of southern East Siberia and south-west of the Russian Far East.

Comment. In habit this new species is similar to a large B. parabidentula, from which, however, differs in not having caducous leaves, obligate epilithic occurrence, and brown to rusty pigmentation (versus leaves easily caducous, almost obligate epixylous occurrence, and green to greenish yellow coloration). In color this species is very similar to B. tricrenata. However the latter has leaves strongly turned to the dorsal side (versus leaves merely straight), mostly trilobed (versus mostly bilobed), wide (length exceeding width 1.11.2 times, versus 1.4-1.7 times), and nearly falcate leaves (versus leaves oblong-ovate).

Bazzania tricrenata (Wahlenb.) Trevis., Mem. Reale Ist. Lombardo Sci., Ser. 3, Cl. Sci. Mat. 4: 415, 1877.

Description. Plants yellowish brownish to greenish brown, forming loose patches, 20-40 $\mathrm{mm}$ long and 750$1250 \mu \mathrm{m}$ wide. Stem easily branched, $125-225 \mu \mathrm{m}$ in diameter, ventral flagellae present, but not numerous. Rhizoids virtually absent. Leaves not caducous, contiguous to distant or subimbricate, obliquely ovate-falcate, with attenuate leaf apex, dorsally insertion line subtransverse to arcuate, ventrally not connate with leaves or connate with one leaf of the pair, 750-1000 $\times 500-750 \mu \mathrm{m}$, strongly turned to ventral side, convex, (2-)3-lobed, lobes strongly unequal, acute, sinus U- to V-shaped. Underleaves erect-spreading, not connate or connate in one side with corresponding leaf, not recurved, 3-4-lobed, with rounded lobes, transversely elliptic. Midleaf cells $17-23 \times 17-20 \mu \mathrm{m}$, thin-walled, trigones moderate in size, concave to triangular, cuticle smooth; cells along margin 12-20 $\mu \mathrm{m}$, external wall not or loosely thickened, cuticle smooth; cuticle in lobe apices smooth; oil bodies smooth surfaced, shortly oblong to nearly spherical or fusiform, biconcentric (having one pupil). (Fig. 6: 3-16; 8; 9: 1-9; 12: A, B)

Ecology. In the Russian Far East this species is generally neutrophilic, although acido- and basi-tolerant mesophyte. It prefers mesic cliff crevices and open (but not in full sun) rocks, rarely occurring in shady sites. It invariable prefers rocky substrates, although sometimes occurs in will exposed humus on steep slopes. Unlike the case in Europe, the species does not occur in swampy areas with hygrophilous mosses. In elevation in the Russian Far East it is a montane taxon, occurring southward of $45-50^{\circ} \mathrm{N}$ in elevation above $800 \mathrm{~m}$ a.s.l., with the exception of one location in the South Kurils where it is known at $400 \mathrm{~m}$ a.s.l. in heathland-like community near the small mountain peak. 


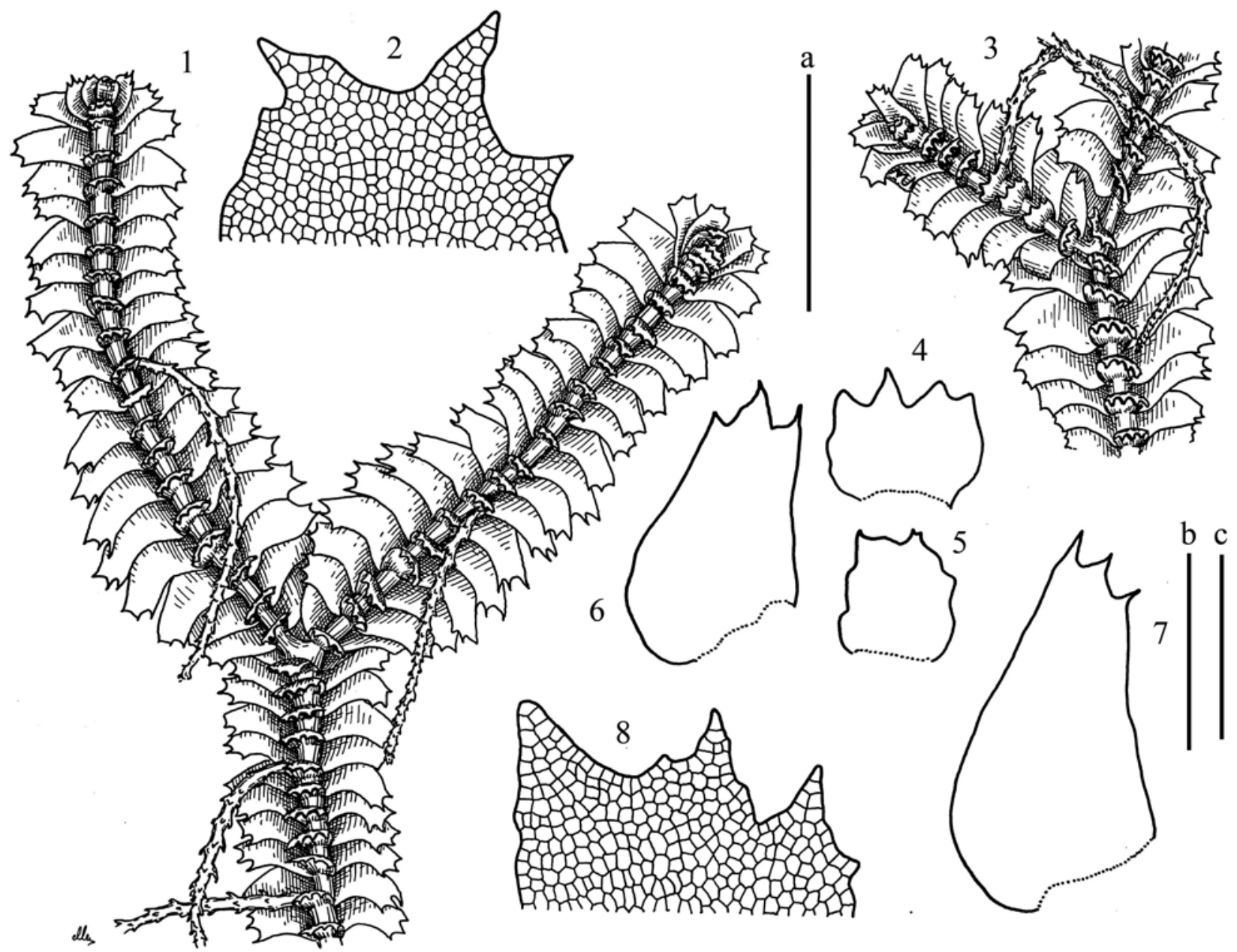

Figure 10 Bazzania japonica (Sande Lac.) Lindb.: 1, 3- plant habit, ventral view; 2, 8- leaf apex; 4, 5- underleaves; 6, 7-leaves (1,2 - from j-40-148-14, VBGI; 3-8 - from isotype of Mastigobryum japonicum Sande Lac., G-00282457/3696). Scales: a - 3 mm, for 1, 3; b - 1 mm, for 4-7; $\mathrm{c}-400 \mu \mathrm{m}$, for 2,8

Northward of $50^{\circ} \mathrm{N}$ the species is a rarity (still not known in Magadan and northward), and it occurs within the range of $500-700 \mathrm{~m}$ a.s.l.

Distribution. A generally circumpolar boreal to oroboreal and subalpine taxon, ranging across mountainous Europe to Ural Mts. and Caucasus. A gap occurs in mountainous areas of China (southward to Taiwan). Northward it occurs in southern portion of Republic of Yakutia and South Siberia and in Pacific side widely distributed in the Russian Far East northward to $59^{\circ}$ N. South of the Far East it is known (and locally abundant) in Korean Peninsula and Japan (up to Kyushu) (Piippo 1990, Yamada \& Iwatsuki 2006, Konstantinova et al. 2009). It is known in the New World in Aleutians and Alaska mainland, southward in California, and then eastward to Ellesmere in the Arctic and Tennessee in the South, being the most northern species in North America (Schuster 1969).

Comments. This taxon was confused for a long time with $B$. denudata in the herbarium. However the following features help to differ both species without doubts: 1) B. tricrenata characterized by green-brown to brown and even rusty and purplish brown color of plants, whereas B. denudata is not able to develop even brown pigmentation (sometimes yellowish pigmentation is present), plants become brownish only after long drying in the herbarium, 2) leaves of B. denudata are slightly obliquely ovate, with commonly truncate apex of nearly the same width with leaf base, versus obliquely ovate-falcate, with tapered leaf apex in B. tricrenata, 3 ) in the region treated both species differ well in ecology and elevation, in that B. tricrenata is a mostly alpine species that only slightly spreads to the subalpine where it grows in open (or nearly so) cliffy habitats, whereas B. denudata is mostly epixylous (although occasionally epilithic and epigeal) preferring shady habitats in hemiboreal, boreal, and subalpine vegetation.

Another problem of delimitation is the morphological relationship of Bazzania tricrenata and the mainly Himalaya-China-Taiwanese-Central Japanese B. imbricata (Mitt.) S. Hatt. that was recently circumscribed based on Japanese materials by Furuki (2015). Taking into account the distribution patterns of the latter, its occurrence in southern part of Sikhote-Alin and Korean Peninsula may be expected. When well developed B. tricrenata and B. imbricata differ in shape and relative width of underleaves (as it was noted by Furuki 2015). However, weak phases may be distinguished with only considerable doubt in dry and old material. I studied ca. 20 specimens collected in Southern Japanese Alps, where B. imbricata seems to be merely common in upper elevations, and found that the only oil bodies' surface character may be suitable for separation of two taxa (this was also 

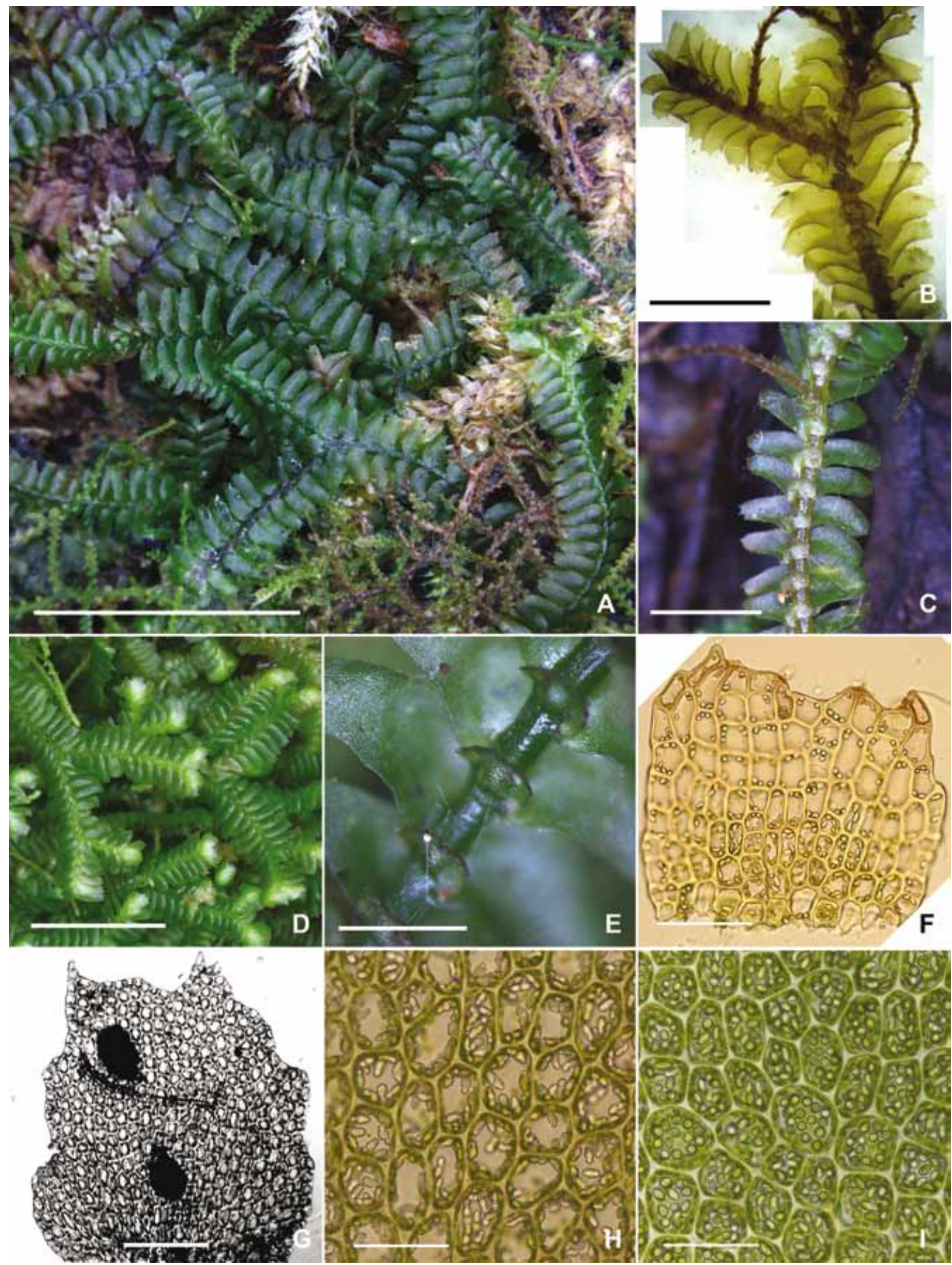

Figure 11 Bazzania japonica (Sande Lac.) Lindb.: A - habit (from j-91-63-15, VBGI); B - habit, ventral view, from isotype; C - habit, ventral view (from j-91-73-15, VBGI); D - habit (from j-11-39-15, VBGI); E - ventral view, fragment (from j-91-63-15, VBGI), F - underleaf (from j-91-63-15, VBGI); $\mathrm{G}$ - underleaf, from isotype; $\mathrm{H}$ - oil bodies in midleaf cells (from j-91-63-15, VBGI); I - oil bodies in the midleaf (from j-11-39-15, VBGI). Scales: A - $10 \mathrm{~mm}, \mathrm{~B}-3 \mathrm{~mm}, \mathrm{C}-3 \mathrm{~mm}, \mathrm{D}-5 \mathrm{~mm}, \mathrm{E}-1 \mathrm{~mm}, \mathrm{~F}-100 \mu \mathrm{m}, \mathrm{G}-100 \mu \mathrm{m}, \mathrm{H}-50 \mu \mathrm{m}, \mathrm{I}-50 \mu \mathrm{m}$. 


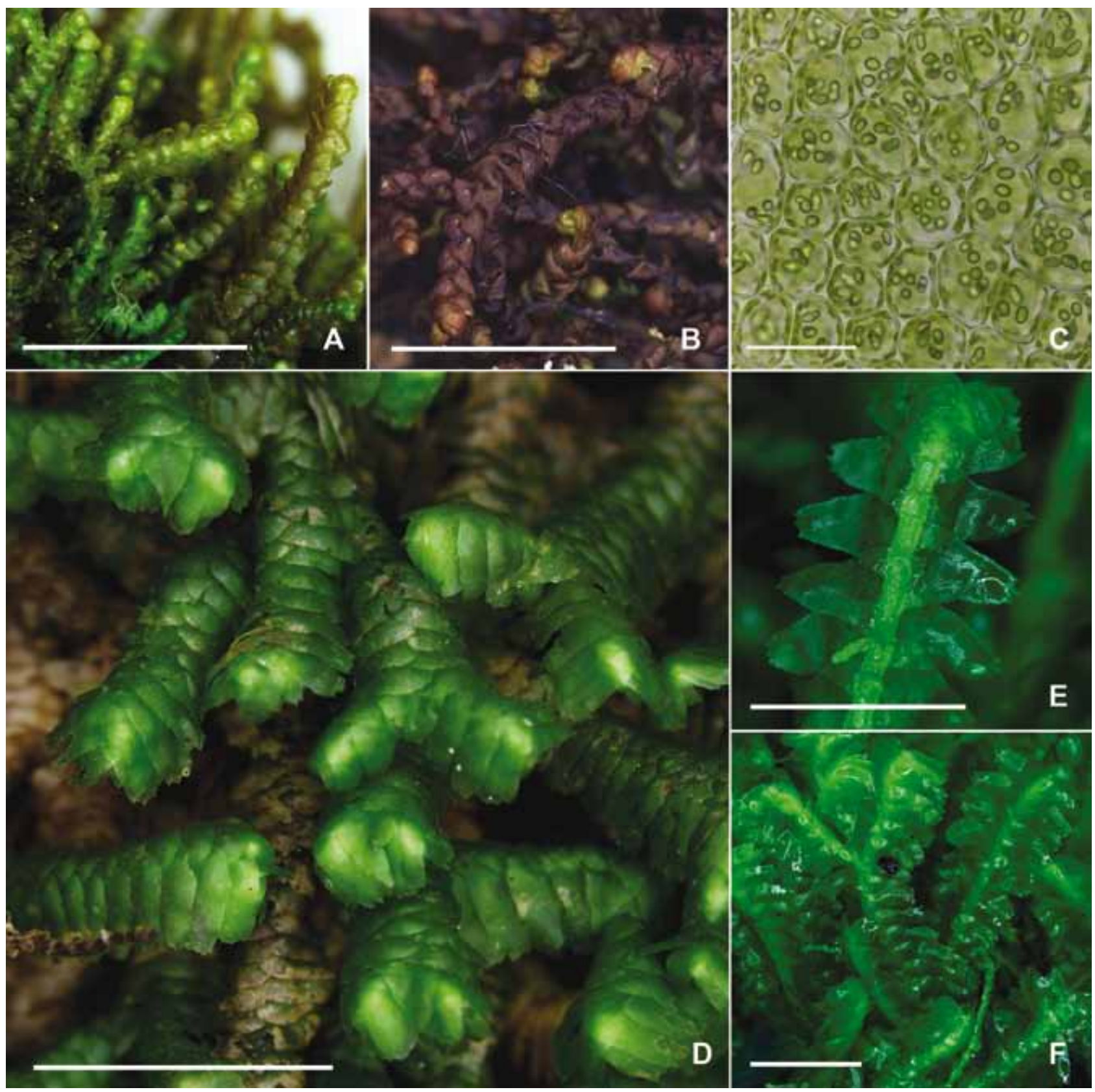

Figure 12 Bazzania tricrenata: A - habit (from kh-41-12-13, VBGI); B - habit, dry condition in herbarium (from p-39-2-14). Bazzania trilobata (L.) Gray: C - oil bodies in the midleaf, from p-39-14-14; D - habit (from p-37-25-14, VBGI); E - habit, ventral view (from p-39-14-14, VBGI); F- habit (from p-39-14-14, VBGI). Scales: A - $5 \mathrm{~mm}, \mathrm{~B}-5 \mathrm{~mm}, \mathrm{C}-50 \mu \mathrm{m}, \mathrm{D}-10 \mathrm{~mm}, \mathrm{E}-5 \mathrm{~mm}, \mathrm{~F}-5 \mathrm{~mm}$

noted by Furuki 2015). Bazzania tricrenata is characterized by smooth surfaced and (at least in the studied populations) biconcentric oil bodies, whereas B. imbricata has finely granulate nonbiconcentric oil bodies.

While studying the set of fresh material from Japan and the Russian Far East, I found this species constantly has biconcentric oil bodies in contrast to the descriptions provided for American and European material (Schuster 1969, Paton 1999, Damsholt 2004). Damsholt (2004), however, provided a figure of oil bodies (plate 172: 6) that may be interpreted as biconcentric, although he wrote (1.c.: 454) only: "with age sometimes segmented". As I found in even very fresh material in East Asia oil bodies distinctly biconcentric that does not relate to the progressing in storage time segmentation. Whether this feature is enough to recognize separate taxon of infraspecific rank was not decided within present account.

[Bazzania japonica (Sande Lac.) Lindb. Acta Soc. Sci. Fenn. 10: 224. 1872. (Mastigobryum japonicum Sande Lac. Ann. Mus. Bot. Lugduno-Batavi 1: 303. 1863. Isotype G00282457/3696!)]

Description. Plants deep green to olive and brownish olive in herbarium, forming loose patches (commonly with admixture of $B$. tridens, also including the type specimen), rigid, 25-60 mm long, 2000-4000 $\mu \mathrm{m}$ wide. Stem easily branched, with numerous ventral flagellae, 250-450 $\mu \mathrm{m}$ in diameter (wider just below bifurcation). Rhizoids virtually absent. Leaves not caducous, subimbricate, slightly convexobcanaliculate, insertion line dorsally oblique to subtrans- 

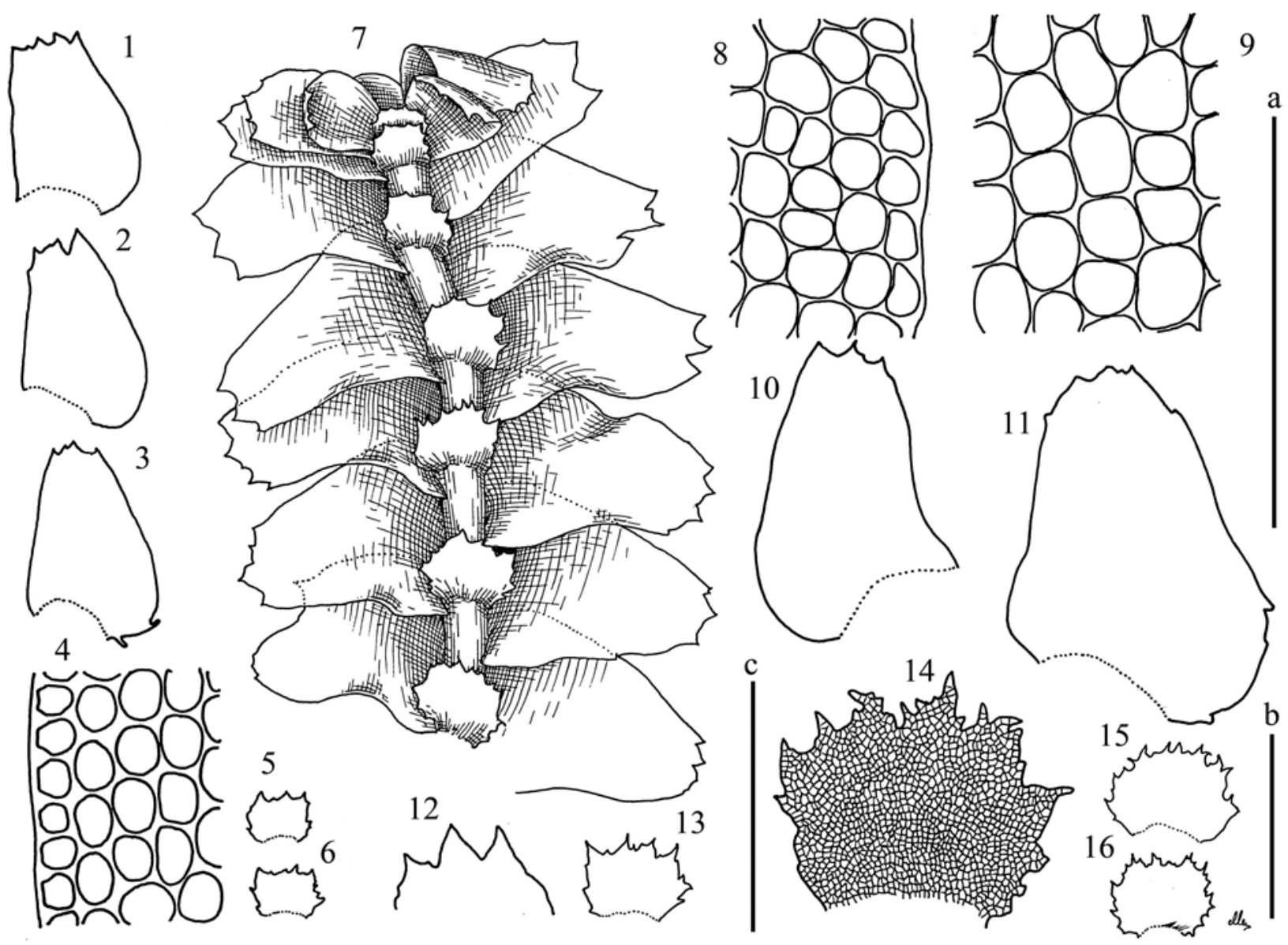

Figure 13 Bazzania trilobata: (L.) Gray: 1-3, 10, 11 - leaves; 4, 8 - cells along leaf margin; 5, 6, 13-16 - underleaves; 9 - cells in the midleaf; 10-11 - leaves; 12 - leaf apex (1-6 - from Roenko E., 05 VIII 2011, n. 22, VBGI; 7-16 - from p-39-14-14, VBGI). Scales: a - 5 mm, for 1-3, 5-7, $10-13,15,16 ; \mathrm{b}-100 \mu \mathrm{m}$, for $4,8,9 ; \mathrm{c}-1 \mathrm{~mm}$, for 14

verse (not arcuate), obliquely ovate-falcate, distinctly trilobed, sometimes with some additional teeth, 1000-2000 $\times$ 670-1200 $\mu \mathrm{m}$. Underleaves connate at the both sides with leaves, recurved along margin, erect-spreading, 600-800 $\times$ 700-800 $\mu \mathrm{m}, 2-5$-lobed (lobes sometimes very short), lobe apices acute, lobes sometimes with additional secondary teeth. Midleaf cells $20-48 \times 22-32 \mu \mathrm{m}$, thin-walled, trigones moderate in size to small, concave to slightly convex, cuticle smooth; cells along leaf margin 15-25 $\mu \mathrm{m}$, thin-walled, external wall thickened, trigones moderate in size to large (especially those adjacent to external side), concave to slightly convex, cuticle smooth; lobe apex cuticle smooth or very indistinctly verrucose; oil bodies homogenous, spherical to oblong, to oblong, fairly segmented to coarsely botryoidal (Fig. 9: 10-17; 10; 11).

Comment. This species occurs on substrata somewhat similar to those of Bazzania denudata, but principally in other macro-communities. It was described from southern Japan, where it seems to be abundant, frequently growing with another noticeably southern taxon, B. tridens. Bazzania japonica prefers warm temperate and subtropical (also mountain) broadleaved deciduous-evergreen and evergreen forests southward from the southern part of Honshu (where B. denudata is restricted to the highest elevations). The species spreads to Indochina (Pocs 1969) and South-East China (Piippo 1990, some records from the latter may be doubtful), whereas the identity of plants from Sumatra may be questionable ('var. sumatrana Herzog'). The species was firstly mentioned for the Russian Far East by Zerov (1962). However, from the phytogeographical point of view these records are very unexpected. Since then, it has been repeatedly recorded, including the last liverwort checklist for Russia (Konstantinova et al. 2009). Recently I had the opportunity to study an isotype of $B$. japonica in $G$ that confirmed the plants in the nomenclatural type are strictly different from those often named as this in the Russian Far East.

As I see it, the basic reason for the misidentification is the naming of any medium-sized Bazzania with recurved underleaves that are connate with leaves as B. japonica in the Russian Far East. Zerov (1962) indicated this feature as the main identification character. The latter was a possible result of Zerov's misinterpretation of the placement B. japonica in 'sect. Connatae' (nom. nud.) proposed by Hattori \& Mizutani (1958). Indeed B. japonica has underleaves connate with leaves in many cases, but Hattori and Mizutani (l.c.) never wrote that $B$. denudata does not have this kind of underleaves. Moreover, in the latter work they compare $B$. denudata with only B. bidentula and did not mention any possibility of mistaking B. japonica with B. denudata. Bazzania japonica has a lot of morphological relatives in the warm temperate-subtropical flora although among Far Eastern taxa resembles only a small $B$. trilobata (due to the absence of incurved to ventral side 'ob-canaliculate' leaves with tapered and somewhat falcate leaf upper third). I think $B$. 
japonica is not present in the Russian Far East, and all known records are based on misidentifications. Bazzania denudata differs from B. japonica in: 1) convex, turned to ventral side (both in wet and dry conditions) leaves, versus leaves obcanaliculate, not turned to ventral side, 2 ) ovate to obliquely ovate leaves with arcuate margins in upper third versus obliquely ovate-falcate leaves with tapered upper third with straight or nearly so margins, and 3) underleaf apices crispate to lobed into rounded to obtuse lobes, versus underleaves dentate or lobed into acute lobes with some additional teeth along margin in B. japonica.

Bazzania trilobata (L.) Gray, Nat. Arr. Brit. Pl. 1: 704, 1821.

Description. Plants prostrate to erect in more or less loose patches, deep green to (rarely) yellowish green or brownish green, however always brightly colored), 50-170 mm long and (3.0-) 4.0-6.5 mm wide. Stem often branched, with numerous ventral flagellae, 380-575 $\mu \mathrm{m}$ in diameter. Rhizoids virtually absent. Leaves not caducous, convex-obcanaliculate, not turned to ventral side when wet and mostly not turned when dry (rarely in dry condition turned to ventral side), contiguous to imbricate or distant in weak phases, $1400-4250 \times 1250-2750 \mu \mathrm{m}$, obliquely ovate to narrowly trapezoidal, with loosely tapered and sometimes falcate apical $1 / 3$, widest near base, apex (2-)3(-4)-lobed, sinus V- to U-shaped, lobes acute, leaves in apical (rarely also basal) third sometimes sparsely dentate or loosely crispate along margin or margin entire, insertion line dorsally distinctly arcuate. Underleaves appressed to the stem or obliquely spreading, 450-900 × 700-1400 $\mu \mathrm{m}$, mostly (East Asian phenotypes) 4-6-lobed, with many additional teeth or coarsely dentate along margin and then not lobed, commonly hyaline along margin (but cells with trigones), not connate with leaves or connate in one side with corresponding leaf. Midleaf cells $22-45 \times 17-33 \mu \mathrm{m}$, thinwalled, trigones moderate to large, convex, cuticle smooth; cells along leaf margin 15-25 $\mu \mathrm{m}$, external wall thickened, trigones adjacent to external wall large and convex, tangential wall thin to unequally thickened, inner wall thin, with moderate to large in size, concave to convex trigones, cuticle smooth; cells in lobe apices with smooth cuticle; oil bodies shortly oblong to irregular in shape, smooth surfaced to loosely segmented. (Fig. 12: C-F; 13)

Ecology. Acidophilic to neutro-tolerant mesophyte, rarely occuring in forest over limestone, but then growing on thick litter, thus on an acidic substrata. In area treated known only from moderately shaded habitats. In northern extremes it grows on litter between and over mosses (most commonly Pleurozium and Hylocomium) under exposed Pinus pumila (then sometimes also on overlying branch bases) and Larix forests. Southward locally abundant in mountain and coastal boreal dark (Picea and Abies) coniferous forests, then continues in mixed broadleaved-coniferous forests (hemiboreal zone or belt), where slightly rarer than in boreal communities. Rarely descends from mixed forests to cool temperate broadleaved forest zone.

Distribution. A boreo-temperate circumpolar taxon. In East Asia it is most frequent in the southern flank of the Russian Far East and (probably) Hokkaido. Northward it becomes more sparse, although it reaches the northern coast of the sea of Okhotsk, where locally abundant in areas not more than $20-25 \mathrm{~km}$ from sea coast (thus under Okhotsk Sea influence). Southward it spreads to the Korean Peninsula, Honshu and Shikoku in Japan. It is supposedly known in southeast China (southwestward of Jiangsu-Yunnan line), but I suspect a mistake in identification. In lower and middle belts of southern flank of South Korea, as well as in southern half of Honshu and Shikoku, the species is replaced in similar habitats (but in principally other communities, e.g. warm temperate evergreen forests) by other taxa, most commonly by the superficially similar Bazzania pompeana (which has a strong difference in underleaves and could be hardly expected in the Russian Far East, although it was identified several times from Sakhalin by F. Stephani, cf. Bakalin \& Katagiri 2014).

\section{SPECIMENS EXAMINED}

\section{Comments:}

1. Only one specimen per locality is cited.

2. Where available, before the collector name the vegetation type is indicated in the brackets in the following generalization and abbreviations: B - boreal coniferous forests (not a monomorphous entity, in mountainous areas of hemiboreal and temperate zones, that is, corresponding mountain belt, where strongly enriched by taxa of adjacent belts); $M$ - mixed broadleaved-dark coniferous hemiboreal forests (that is, so-called Manchurian forests in continental part of the Russian Far East and Koreas, and is rather different in structure, composition, moisture conditions, etc., from hemiboreal mixed forests of Japan and insular part of the Russian Far East); W'T - warm temperate broadleaved mostly evergreen forest; $\mathrm{S}$ - subtropical evergreen forest with some tropical elements; CT - cool temperate broadleaved deciduous forest; $\mathrm{H}$ - heathlands (rather heterogenous entity including: a) forestless landscapes near the peaks of some not high southern mountains without typical alpine or tundra species, b) similar to latter 'tundroid' communities near sea coast formed under severe wind regime, c) natural meadows near sea coast on steep slopes and with many rocky outcrops, formed under severe wind regime in temperate zones); $\mathrm{C}$ - crooked forest, that is, typical dwarf forest communities formed by Pinus pumila and Alnus fruticosa; Betula ermanii forests in eastern flanks of boreal and hemiboreal East Asia referred to this type too; C + Sasathe combination of the type of crooked forest described above, and communities with Sasa dominance; A - typical mountain tundras; Hem - typical hemiarctic communities, here meaning lighted Larix forest with tundra-like communities between clumps.

3. Collector name is given in full with the exception for V.A. Bakalin abbreviated as VB.

\section{Bazzania japonica}

CHINA: Anhwei Province: Huangshan Mt., 1420 m alt., leg. 17.5.1982 Gao Chien, 30514 (NICH 410002); HunAN Province: Monshan Mts., 970 m alt., leg. 05.IX. 1974 Lim Ban Zian, s.n. (NICH 410003); INDIA: Ceylon: Hiniduma, Haycock, $600 \mathrm{~m}$ alt., leg. 041976 Onraedt M., 3466 (NICH 374012); JAPAN: EhIme Pref.: Higashi-akaishi Mt. leg. VII 1948 Oti K., 2599 (NICH 14275); Higo Pref.: Hitoyoshi leg. 5.6.1947 Mayebara K., 389 (NICH 11062); HokKaido Pref.: Atsukeshi-cho, leg. 1.7.1999 Izawa M., s.n. (NICH 242744); Kagoshima Pref.: Amami-ohshima 
Island, Yuwan Mt., 400-500 m alt., (WT) leg. 27.12.1981 Iwatsuki Z., 10432 (NICH 185370); Yakushima Island, 50-100 m alt., (WT) leg. 08 IX 1968 Takaki N. and M. Mizutani, 308 (NICH 93453); KochI Pref.: Shiofuri Falls $\left(33^{\circ} 48^{\prime} 09^{\prime \prime} \mathrm{N} 133^{\circ} 41^{\prime} 15^{\prime \prime E}\right), 500 \mathrm{~m}$ alt. (WT) 25.3.2015 VB, j-11-39-15 (VBGI); Miyazaki Pref.: Inohae Valley $\left(31^{\circ} 44^{\prime} \mathrm{N} 131^{\circ} 22^{\prime} \mathrm{E}\right), 300 \mathrm{~m}$ alt., (WT) leg. 1.10.2014 VB, j-40-148-14 (VBGI); Kaeda Stream Valley. (314ㄴ'49"N $\left.131^{\circ} 22^{\prime 2} 29^{\prime \prime E}\right), 180-215 \mathrm{~m}$ alt. (WT) 7.10. $2015 \mathrm{VB}, \mathrm{j}-91-63-$ 15, k-91-73-15 (VBGI); Nagano Pref.: Yatsu Mt., 1600$2000 \mathrm{~m}$ alt., (M) leg. 8.1957 Inoue H., 7553 (NICH 37997); Nara Pref.: Kawakamimura, 490 m alt., (S) leg. 25 VI 1996 Toyoda et al., 96143 (NICH 231968); OKINAWA PREF.: Iriomote Island, 10-400 m alt., (S) leg. 02011977 Iwatsuki Z., 2923 (NICH 155106); Shiga Pref.: Azuchi, 50-150 m alt., (WT) leg. 15.10.1967 Kodama T. and M. Mizutani, 443 (NICH 82887); Shizuoka Pref.: Kiriyama, $500 \mathrm{~m}$ alt., (WT) leg. 20.9.1959 Sugino T., 40977 (NICH 45169).

\section{Bazzania manczurica}

JAPAN: Gifu Pref.: Ontake Mt. leg. 28 VIII 1953 Fukuhara M., 47 (NICH 233118); REPUBLIC OF KOREA: Deokgyu Mts. (35 52'N $\left.127^{\circ} 46^{\prime} \mathrm{E}\right), 951 \mathrm{~m}$ alt., (CT) leg. 24

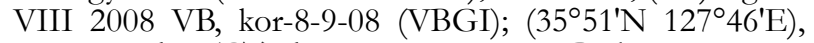
$1196 \mathrm{~m}$ alt., (CT) leg. 26 VI 2008 VB, kor-11-29a-08 (VBGI); (3551'N $\left.127^{\circ} 45^{\prime} \mathrm{E}\right), 1576 \mathrm{~m}$ alt., (M) leg. $25 \mathrm{VI}$

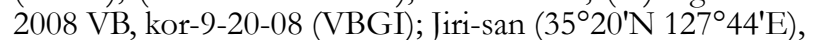
$1650 \mathrm{~m}$ alt., (B) leg. 16 VI $2009 \mathrm{VB}$, kor-12-12b-09 (VBGI),

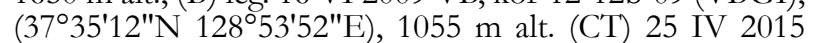

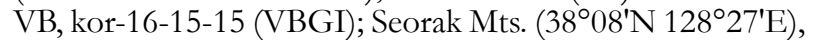
$1550 \mathrm{~m}$ alt., (M) leg. $12 \mathrm{~V} 2011 \mathrm{VB}$, kor-10-11-11 (VBGI); $\left(38^{\circ} 07^{\prime} \mathrm{N} 128^{\circ} 27^{\prime} \mathrm{E}\right), 1250 \mathrm{~m}$ alt., (M) leg. $11 \mathrm{~V} 2011 \mathrm{VB}$, kor7-25-11 (VBGI); (3808' $\left.\mathrm{N} 128^{\circ} 27^{\prime} \mathrm{E}\right), 1550 \mathrm{~m}$ alt., (M) leg.

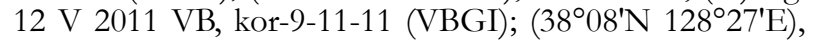
$1400 \mathrm{~m}$ alt., (M) leg. $11 \mathrm{~V} 2011 \mathrm{VB}$, kor-8-10-11 (VBGI); RUSSIA: BuRYATIA REPUBlic: Khamar-Daban Mts., Osinovsky Golets $\left(51^{\circ} 32^{\prime} \mathrm{N} 105^{\circ} 25^{\prime} \mathrm{E}\right)$, m alt., (B) leg. 15 VIII 2001 Konstantinova N.A., 113-3-01 (KPABG 104312); Primorsky Territory: Lazovsky District (M) leg. $20 \mathrm{~V}$ 1982 Bardunov L.V. \& V.Ya. Cherdantseva, s.n. (KPABG 104767); Olkhovaya Mt. (43⒉ $\left.21^{\prime} \mathrm{N} 133^{\circ} 39^{\prime} \mathrm{E}\right), 1600 \mathrm{~m}$ alt., (H) leg. 10 IX 2013 VB, p-44-26-10 (VBGI); (4321'N $\left.133^{\circ} 39^{\prime} \mathrm{E}\right), 1000 \mathrm{~m}$ alt., (B) leg. 11 IX $2010 \mathrm{VB}, \mathrm{p}-45-33-10$ (VBGI); (43⒉ $\left.21^{\prime} \mathrm{N} 133^{\circ} 40^{\prime} \mathrm{E}\right), 1200 \mathrm{~m}$ alt., (M) leg. $13 \mathrm{IX}$ $2014 \mathrm{VB}, \mathrm{p}-36-11-14$ (VBGI); (43⒉'N 13340'E), $1200 \mathrm{~m}$ alt., (M) leg. 13 IX 2014 VB, p-36-7-11, p-36-11-14 (VBGI); (432' $\left.\mathrm{N} 133^{\circ} 39^{\prime} \mathrm{E}\right), 1500 \mathrm{~m}$ alt., (B) leg. 03 X $2006 \mathrm{VB}, \mathrm{p}-$ 65-9a-06 (VBGI); (432ำ $\left.\mathrm{N} 133^{\circ} 39^{\prime} \mathrm{E}\right), 1500 \mathrm{~m}$ alt., (B) leg. 02 X 2006 VB, p-64-9-06 (VBGI); Puzikov Pass (4339'N 1333'ㄹ), $1250 \mathrm{~m}$ alt., (B) leg. 14 IX $2014 \mathrm{VB}, \mathrm{p}-37-3-14$

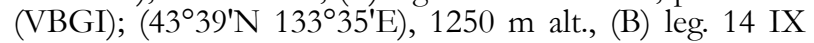
2014 VB, p-37-35-14, p-37-36-14 (VBGI); Snezhnaya Mt. $\left(43^{\circ} 40^{\prime} \mathrm{N} 134^{\circ} 25^{\prime} \mathrm{E}\right), 820 \mathrm{~m}$ alt., (M) leg. $15 \mathrm{IX} 2014 \mathrm{VB}$, p-39-20-14 (VBGI); (4336' $\left.\mathrm{N} 134^{\circ} 13^{\prime} \mathrm{E}\right), 600 \mathrm{~m}$ alt., (M) leg. 16 IX 2007 VB, p-70-11-07 (VBGI); Sakhalin Pro-

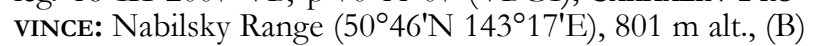
leg. 16 VIII 2006 VB, s-29-12-06 (VBGI).

\section{Bazzania denudata}

JAPAN: Aomori Pref.: Hakkoda Mt. (B) leg. 15 VII 1939 Morioka and Hurusawa, s.n. (NICH 2500); HokKaIdo Pref.: Asahidake Mt., $1050 \mathrm{~m}$ alt., (B) leg. 24 VII $1956 \mathrm{Ku}-$ wahara Y., 5616 (NICH 63249); Daisetsu Mt. (B) leg. 29 VII 1950 Sasaki T., 522 (NICH 17033); Ishokari: Daisetsu Mt. (B) leg. 29 VII 1950 Sasaki T., 520 (NICH 17032); Kurodake Mt., 1200-1300 m alt., (B) leg. 21 VII 1956 Kuwahara Y., 5653 (NICH 63254); Rishiri, $5 \mathrm{~m}$ alt., (H) leg. 19 VIII 1971 Iwatsuki Z., 2043 (NICH 122089); Nagano Pref.: Ontake Mt., 1000-2100 m alt., (CT) leg. 22 VIII 1973 Yoshimura I. and K. Yamada, 123 (NICH 144326); NARA Pref.: Kongo Mt., 1100 m alt., (CT) leg. 29031959 Kodama T.,
14264 (NICH 46021); Niigata Pref.: Tadara Ridge, $930 \mathrm{~m}$ alt., (B) leg. 13.6. 1971 Honma K., 5368 (NICH 241423); Toyama Pref.: Tateyama Mt., 1890-2000 m alt., (B) leg. 19 VIII 1973 Yoshimura I. and K. Yamada, 4070 (NICH 144263); REPUBLIC OF KOREA: Deokgyu Mts. $\left(35^{\circ} 51^{\prime} \mathrm{N} 127^{\circ} 45^{\prime} \mathrm{E}\right), 1576 \mathrm{~m}$ alt., (M) leg. $25 \mathrm{VI} 2008 \mathrm{VB}$, kor-9-4-08 (VBGI); Jiri-san (35 $\left.20^{\prime} \mathrm{N} 127^{\circ} 44^{\prime} \mathrm{E}\right), 1121 \mathrm{~m}$ alt., (CT) leg. 14 VI $2009 \mathrm{VB}$, kor-5-9-09 (VBGI); $\left(35^{\circ} 20^{\prime} \mathrm{N}\right.$ $127^{\circ} 44^{\prime} \mathrm{E}$ ), $1800 \mathrm{~m}$ alt., (M) leg. 14 VII $2009 \mathrm{VB}$, kor-10-3009 (VBGI); Seorak Mts. (38 $\left.08^{\prime} \mathrm{N} 128^{\circ} 27^{\prime} \mathrm{E}\right), 1550 \mathrm{~m}$ alt., (M) leg. 12 V 2011 VB, kor-9-05-11 (VBGI); (38 $08^{\circ} \mathrm{N}$ $\left.128^{\circ} 27^{\prime} \mathrm{E}\right), 1550 \mathrm{~m}$ alt., (M) leg. $12 \mathrm{~V} 2011 \mathrm{VB}$, kor-9-16-11 (VBGI); $\left(38^{\circ} 08^{\prime} \mathrm{N} 128^{\circ} 27^{\prime} \mathrm{E}\right), 800 \mathrm{~m}$ alt., (CT) leg. $11 \mathrm{~V}$ 2011 VB, kor-5-11 (VBGI); RUSSIA: KaMchatKa TERRITORY: Bystrinsky District, Icha River upper course (C) leg. 14 IX 2002 Bakalin V.A., K-50-8-02 (KPABG 104103); Khabarovsk Territory: Bolshekhekhtsirsky Reserve (B) leg. 18 IX 1982 Gambaryan S.K., s.n. (VBGI); Dusse-Alin Range $\left(52^{\circ} 04^{\prime} \mathrm{N} 134^{\circ} 55^{\prime} \mathrm{E}\right), 1400 \mathrm{~m}$ alt., (C) leg. VIII 1992 Kurilin G.N., s.n. (VBGI); Tardoki-Yani Mts. $\left(48^{\circ} 50^{\prime} \mathrm{N}\right.$ $\left.138^{\circ} 05^{\prime} \mathrm{E}\right), 765 \mathrm{~m}$ alt., (B) leg. 20 VIII $2013 \mathrm{VB}$, kh-32-3613 (VBGI); (48 52'N 138 $\left.04^{\circ} \mathrm{E}\right), 1300 \mathrm{~m}$ alt., (B) leg. 28 VIII 2012 Malashkina E.V., s.n. (VBGI); (48 $50^{\circ} \mathrm{N}$ $\left.138^{\circ} 06^{\prime} \mathrm{E}\right), 617 \mathrm{~m}$ alt., (M) leg. 28 VIII 2013 VB, kh-45-2813 (VBGI); Magadan Province: Magadan City $\left(59^{\circ} 31^{\prime} \mathrm{N}\right.$ $\left.150^{\circ} 40^{\prime} \mathrm{E}\right), 10 \mathrm{~m}$ alt., (C) leg. $13 \mathrm{VIII} 2013 \mathrm{VB}$, mag-28-8-13 (VBGI); Primorsky Territory: Anikin Klyuch $\left(43^{\circ} 41^{\prime} \mathrm{N}\right.$ $\left.132^{\circ} 30^{\prime} \mathrm{E}\right), 240 \mathrm{~m}$ alt., (M) leg. 14 X $2008 \mathrm{VB}, \mathrm{p}-62-12-08$ (VBGI); Artyomovka River $\left(43^{\circ} 42^{\prime} \mathrm{N} 132^{\circ} 34^{\prime} \mathrm{E}\right), 229 \mathrm{~m}$ alt., (M) leg. 16 X 2008 VB, p-68-5-08 (VBGI); Bikin River (B) leg. 28 VI 1993 Gambaryan S.K., s.n. (VBGI); Chandolaz Range $\left(42^{\circ} 58^{\prime} \mathrm{N} 133^{\circ} 02^{\prime} \mathrm{E}\right), 148 \mathrm{~m}$ alt., (CT) leg. $19 \mathrm{X} 2005$ VB, p-76-32-05 (VBGI); Chuguyevsky District, 1800? m alt., (B) leg. 20 IX 1980 Gambaryan S.K., s.n. (KPABG 104760); leg. 19 IX 1980 Gambaryan S.K., s.n. (KPABG 109199); Dal'Negorsky District leg. 21 VII 1976 Gambaryan S.K., s.n. (KPABG 104768); Elomovsky Stream (4314'N $\left.133^{\circ} 44^{\prime} \mathrm{E}\right), 350 \mathrm{~m}$ alt., (M) leg. 23 IX $2011 \mathrm{VB}, \mathrm{p}-74-10-11$

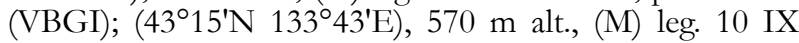
2014 VB, p-34-14-14 (VBGI); Falaza Mt. $\left(43^{\circ} 08^{\prime} \mathrm{N}\right.$ $\left.132^{\circ} 48^{\prime} \mathrm{E}\right), 400 \mathrm{~m}$ alt., (M) leg. 27 VI $2012 \mathrm{VB}, \mathrm{p}-20-25-12$

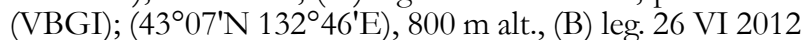
VB, p-16-22-12 (VBGI); (43ํำ $\left.132^{\circ} 47^{\prime} \mathrm{E}\right), 800 \mathrm{~m}$ alt., (B) leg. 26 VI 2012 VB, p-16-6-12 (VBGI); $\left(43^{\circ} 06^{\prime} \mathrm{N}\right.$ $\left.132^{\circ} 47^{\prime} \mathrm{E}\right), 1100 \mathrm{~m}$ alt., (B) leg. 26 VI $2012 \mathrm{VB}, \mathrm{p}-18-12-12$ (VBGI); leg. 07 VIII 1978 Gambaryan S.K., s.n. (VBGI); Glubinnoye (B) leg. 18 VI 1991 Gambaryan S.K., s.n. (VBGI); Kavalerovo $\left(44^{\circ} 15^{\prime} \mathrm{N} 135^{\circ} 03^{\prime} \mathrm{E}\right), 321 \mathrm{~m}$ alt., (M) leg. 17 IX 2011 VB, p-68-15-11 (VBGI); Kedrovaya Pad' (43ํำ' $\left.131^{\circ} 31^{\prime} \mathrm{E}\right), 500 \mathrm{~m}$ alt., (M) leg. $18 \mathrm{~V} 2007 \mathrm{VB}, \mathrm{p}-3-$ 22-07 (VBGI); (4306' $\left.\mathrm{N} 131^{\circ} 31^{\prime} \mathrm{E}\right), 286 \mathrm{~m}$ alt., (M) leg. 17 V 2007 VB, p-2-29-07 (VBGI); (43으' $\left.06^{\prime} \mathrm{N} 131^{\circ} 31^{\prime} \mathrm{E}\right), 500 \mathrm{~m}$ alt., (M) leg. 18 V 2007 VB, p-3-36-07 (VBGI); Krasnoarmeysky District leg. 19 VI 1991 Gambaryan S.K., s.n. (KPABG 104757); Krinichnaya Mt. (M) leg. 14 VII 1980 Gambaryan S.K., s.n. (VBGI); Lazovsky District, Petrov Island leg. 25 VIII 1986 Cherdantseva V.Ya., s.n. (KPABG 104756); (H) leg. 18 IX 1987 Gambaryan S.K., s.n. (VBGI); Lozovaya Mt., $1150 \mathrm{~m}$ alt., (B) leg. 16 VII 1982 Gambaryan S.K., s.n. (VBGI); Oblachnaya Mt. $\left(43^{\circ} 41^{\prime} \mathrm{N} 134^{\circ} 08^{\prime} \mathrm{E}\right), 850$ $\mathrm{m}$ alt., (B) leg. 17 VIII 2007 Cherdantseva V.Ya., s.n. (VBGI); (B) leg. 20 IX 1980 Gambaryan S.K., s.n. (VBGI); $1800 \mathrm{~m}$ alt., (C) leg. 20 IX 1980 Gambaryan S.K., s.n.

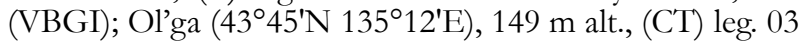

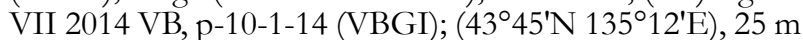
alt., (H) leg. 22 IX 2007 VB, p-84-12-07 (VBGI); (CT) leg. 14 VII 1980 Gambaryan S.K., s.n. (VBGI); (H) leg. s.d. Gambaryan S.K., s.n. (VBGI); Olkhovaya Mt. $\left(43^{\circ} 21^{\prime} \mathrm{N}\right.$ $\left.133^{\circ} 39^{\prime} \mathrm{E}\right), 1600 \mathrm{~m}$ alt., (H) leg. $10 \mathrm{IX} 2013 \mathrm{VB}, \mathrm{p}-44-51-10$ (VBGI); $\left(43^{\circ} 27^{\prime} \mathrm{N} 133^{\circ} 38^{\prime} \mathrm{E}\right), 1660 \mathrm{~m}$ alt., (H) leg. 12 IX 2014 VB, p-35-28-14 (VBGI); Petrova Island (M) leg. 25 
VIII 1986 Gambaryan S.K., s.n. (VBGI); Pidan Mt. $\left(43^{\circ} 04^{\prime} \mathrm{N} 132^{\circ} 41^{\prime} \mathrm{E}\right), 1100 \mathrm{~m}$ alt., (B) leg. 06 IX $2010 \mathrm{VB}$, p-37-6-10 (VBGI); (43ํำ $\left.132^{\circ} 42^{\prime} \mathrm{E}\right), 1200 \mathrm{~m}$ alt., (B) leg. 10 X $2005 \mathrm{VB}, \mathrm{p}-74-5-05$ (VBGI); (430' $\left.\mathrm{N} 132^{\circ} 42^{\prime} \mathrm{E}\right), 500$ $\mathrm{m}$ alt., (B) leg. 06 X $2008 \mathrm{VB}, \mathrm{p}-53-5-08$ (VBGI); $\left(43^{\circ} 06^{\prime} \mathrm{N}\right.$ $\left.132^{\circ} 42^{\prime} \mathrm{E}\right), 535 \mathrm{~m}$ alt., (B) leg. 09 X $2005 \mathrm{VB}, \mathrm{p}-73-1-05$ (VBGI); (4306' $\left.\mathrm{N} 132^{\circ} 41^{\prime} \mathrm{E}\right), 444 \mathrm{~m}$ alt., (M) leg. $06 \mathrm{X} 2008$

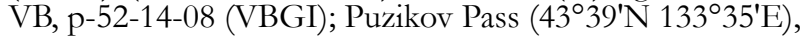
$1250 \mathrm{~m}$ alt., (B) leg. 14 IX $2014 \mathrm{VB}, \mathrm{p}-37-36 a-14$ (VBGI); Sikhote-Alin Reserve (B) leg. 10 VIII 1995 Gambaryan S.K., s.n. (VBGI); (B) leg. 11 VII 1994 Gambaryan S.K., s.n. (VBGI); (B) leg. 30 IX 1997 Gambaryan S.K., s.n. (VBGI); $600 \mathrm{~m}$ alt., (B) leg. 12 VII 1994 Gambaryan S.K., s.n. (VBGI); 900 m alt., (B) leg. 23 VII 1994 Gambaryan S.K., s.n. (VBGI); (B) leg. 02 VIII 1995 Gambaryan S.K., s.n.

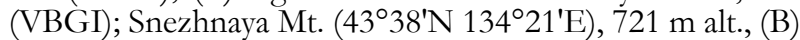

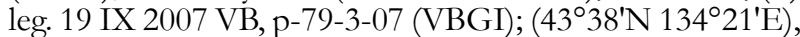
$721 \mathrm{~m}$ alt., (B) leg. 19 IX $2007 \mathrm{VB}, \mathrm{p}-79-6-07$ (VBGI); $\left(43^{\circ} 36^{\prime} \mathrm{N} 134^{\circ} 13^{\prime} \mathrm{E}\right), 600 \mathrm{~m}$ alt., (M) leg. 16 IX $2007 \mathrm{VB}$,

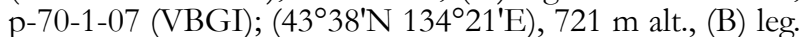

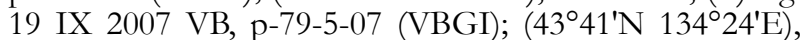
$861 \mathrm{~m}$ alt., (B) leg. 16 IX 2007 VB, p-71-11-07 (VBGI); Solnechnava Pad $\left(43^{\circ} 27^{\prime} \mathrm{N} 134^{\circ} 13^{\prime} \mathrm{E}\right), 800 \mathrm{~m}$ alt., (M) leg. $21 \mathrm{IX}$ 2012 VB, p-45-14-12 (VBGI); Solontsovaya River (433' $\mathrm{N}$ $134^{\circ} 41^{\prime} \mathrm{E}$ ), $386 \mathrm{~m}$ alt., (M) leg. 21 IX $2007 \mathrm{VB}, \mathrm{p}-82-10-07$ (VBGI); Terneysky District (Sakhote-Alin Reserve) leg. 25 IX 1997 Gambaryan S.K., s.n. (KPABG 104766); (M) leg. 10 VIII 1995 Gambaryan S.K., s.n. (KPABG 104759); Vladimir Bay $\left(43^{\circ} 53^{\prime} \mathrm{N} 135^{\circ} 31^{\prime} \mathrm{E}\right), 25 \mathrm{~m}$ alt., (H) leg. $21 \mathrm{IX}$ 2007 VB, p-83-10-07 (VBGI); SaKhalin Province: Iturup Island $\left(45^{\circ} 16^{\prime} \mathrm{N} 148^{\circ} 10^{\prime} \mathrm{E}\right), 15 \mathrm{~m}$ alt., (C) leg. $22 \mathrm{IX} 2005$

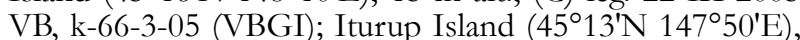
$75 \mathrm{~m}$ alt., (C + Sasa) leg. 11 VIII $2005 \mathrm{VB}, \mathrm{k}-45-22-05$ (VBGI); $\left(45^{\circ} 15^{\prime} \mathrm{N} 148^{\circ} 02^{\prime} \mathrm{E}\right), 20 \mathrm{~m}$ alt., (CT) leg. $21 \mathrm{IX}$ $2005 \mathrm{VB}, \mathrm{k}-65-5-05$ (VBGI); $\left(45^{\circ} 05^{\prime} \mathrm{N} 148^{\circ} 00^{\prime} \mathrm{E}\right), 409 \mathrm{~m}$ alt., (C + Sasa) leg. 15 IX 2005 VB, k-56-19-05 (VBGI); $\left(44^{\circ} 46^{\prime} \mathrm{N} 147^{\circ} 11^{\prime} \mathrm{E}\right), 15 \mathrm{~m}$ alt., (B) leg. 16 VIII $2007 \mathrm{VB}$,

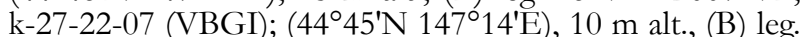

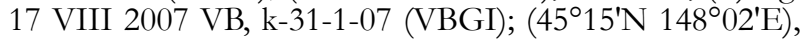
$20 \mathrm{~m}$ alt., (M) leg. $21 \mathrm{IX} 2005 \mathrm{VB}, \mathrm{k}-65-21-05$ (VBGI); $\left(45^{\circ} 13^{\prime} \mathrm{N} 147^{\circ} 50^{\prime} \mathrm{E}\right), 75 \mathrm{~m}$ alt., (CT) leg. $27 \mathrm{~V} 2006 \mathrm{VB}$, k-45-15-05 (VBGI); (44ํำ' $\left.146^{\circ} 11^{\prime} \mathrm{E}\right), 15 \mathrm{~m}$ alt., (B) leg.

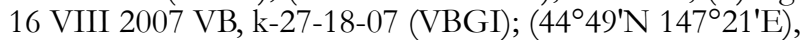
$50 \mathrm{~m}$ alt., (B) leg. 20 VIII 2007 VB, k-35-13-07 (VBGI); $\left(45^{\circ} 21^{\prime} 45^{\prime \prime N} 148^{\circ} 37^{\prime} 13^{\prime \prime E}\right), 23 \mathrm{~m}$ alt. (C + Sasa) 10 IX 2015

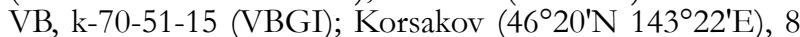
m alt., (B) leg. 16 IX 2009 VB, s-66-15-09 (VBGI); Kunashir Island $\left(43^{\circ} 53^{\prime} \mathrm{N} 145^{\circ} 28^{\prime} \mathrm{E}\right), 30 \mathrm{~m}$ alt., (H) leg. 06 IX 2007 VB, k-46-11-06 (VBGI); (4352'N 14530'E), $180 \mathrm{~m}$ alt., (B) leg. 04 IX $2006 \mathrm{VB}, \mathrm{k}-45-20-06$ (VBGI); (442ㅇ' $\left.146^{\circ} 06^{\prime} \mathrm{E}\right)$, $38 \mathrm{~m}$ alt., (M) leg. 27 VIII $2006 \mathrm{VB}, \mathrm{k}-36-7-06$ (VBGI);

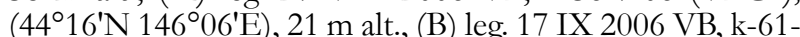
1-06 (VBGI); $\left(44^{\circ} 28^{\prime} \mathrm{N} 146^{\circ} 07^{\prime} \mathrm{E}\right), 300 \mathrm{~m}$ alt., (B) leg. 28

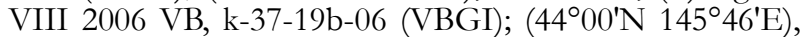
$60 \mathrm{~m}$ alt., (M) leg. $10 \mathrm{IX} 2006 \mathrm{VB}, \mathrm{k}-53-4 \mathrm{~b}-06$ (VBGI); $\left(43^{\circ} 53^{\prime} \mathrm{N} 145^{\circ} 28^{\prime} \mathrm{E}\right), 30 \mathrm{~m}$ alt., (CT) leg. 06 IX $2006 \mathrm{VB}, \mathrm{k}-$

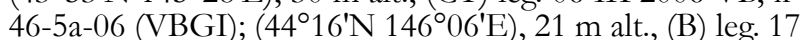
IX 2007 VB, k-61-4a-06 (VBGI); Nabilsky Range (5047'N $\left.143^{\circ} 16^{\prime} \mathrm{E}\right), 700 \mathrm{~m}$ alt., (B) leg. 12 IX $2009 \mathrm{VB}, \mathrm{s}-63-9-09$ (VBGI); Nevelsk $\left(46^{\circ} 44^{\prime} \mathrm{N} 142^{\circ} 01^{\prime} \mathrm{E}\right), 311 \mathrm{~m}$ alt., (M) leg. 17 IX 2009 VB, s-68-5-09 (VBGI); (46 $\left.44^{\circ} \mathrm{N} 142^{\circ} 08^{\prime} \mathrm{E}\right), 242$ $\mathrm{m}$ alt., (CT) leg. 17 IX $2009 \mathrm{VB}, \mathrm{s}-67-9-09$ (VBGI); (4644'N $142^{\circ} 01^{\prime} \mathrm{E}$ ), $311 \mathrm{~m}$ alt., (M) leg. 17 IX $2009 \mathrm{VB}, \mathrm{s}-68-13-09$

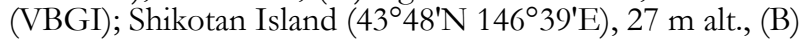
leg. 27 VIII 2007 VB, k-47-20-07 (VBGI); (434ㅇ' $146^{\circ} 36^{\prime} \mathrm{E}$ ), $110 \mathrm{~m}$ alt., (B) leg. $30 \mathrm{VIII} 2007 \mathrm{VB}, \mathrm{k}-50-32-07$ (VBGI); (434' $\left.\mathrm{N} 146^{\circ} 41^{\prime} \mathrm{E}\right), 50 \mathrm{~m}$ alt., (B) leg. 02 IX 2007 VB, k-57-14-07 (VBGI); (43ํำ' $\left.146^{\circ} 44^{\prime} \mathrm{E}\right), 320 \mathrm{~m}$ alt., (H) leg. 25 VIII $2007 \mathrm{VB}, \mathrm{k}-42-17-07$ (VBGI); $\left(43^{\circ} 48^{\prime} \mathrm{N}\right.$ $\left.146^{\circ} 39^{\prime} \mathrm{E}\right), 120 \mathrm{~m}$ alt., (B) leg. 28 VIII $2007 \mathrm{VB}, \mathrm{k}-49-47-07$

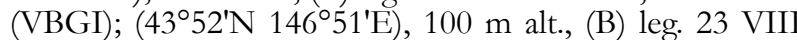

2007 VB, k-36-16-07 (VBGI); (43ํ7'N 146²4'E), $320 \mathrm{~m}$

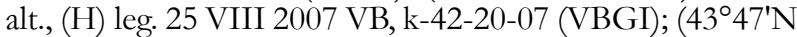
$\left.146^{\circ} 41^{\prime} \mathrm{E}\right), 200 \mathrm{~m}$ alt., (H) leg. 25 VIII $2007 \mathrm{VB}, \mathrm{k}-41-5-07$

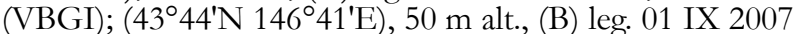

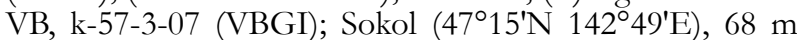
alt., (B) leg. 12 VIII 2006 VB, s-25-20-06 (VBGI); Zhdanko

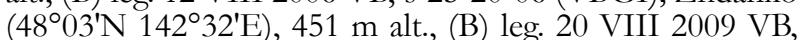
s-25-19-09 (VBGI).

\section{Bazzania parabidentula}

JAPAN: Ehime Pref.: Omogokei Mt., 950-980 m alt., (CT) leg. 30 V 1962 Ueta Y., 225 (NICH 69880); FukushimA Pref.: Higashi-azuma Mt., $1600 \mathrm{~m}$ alt., (CT) leg. $10 \mathrm{VIII}$ 1979 Mizutani M., 5775 (NICH 174455); Tsuchiyu, 500 $1200 \mathrm{~m}$ alt., (CT) leg. 15 IX 1969 Higuchi T., s.n. (NICH 103228); GIFu Pref.: Gozen Mt., $900 \mathrm{~m}$ alt., (CT) leg. 0304 1969 Ogasawara S., s.n. (NICH 104590); 900-1100 m alt., (CT) leg. 11 X 1970 Magofuku T., 7422 (NICH 234625); Ontake Mt., 1700-1800 m alt., (M) leg. 20 VIII 1970 Koponen T., 16450 (NICH 116737); Hokkaido Pref.: Asahidake Mt., 1050 m alt., (B) leg. 24 VII 1956 Kuwahara Y., 5640 (NICH 63345); $1300 \mathrm{~m}$ alt., (B) leg. 23 VII $1956 \mathrm{Ku}-$ wahara Y., 5641 (NICH 63269); Sounkyo Valley - Kurodake Mt., 1400-1500 m alt., (B) leg. 21 VII 1956 Kuwahara Y., 5600 (NICH 63270); Nagano Pref.: Ontake Mt., 2100_ $2250 \mathrm{~m}$ alt., (B) leg. 22 VIII 1973 Yamada K., 12062 (NICH 234793); Senjoo Mt., 1600-1800 m alt., (M) leg. 24 VII 1958 Inoue H., 8206 (NICH 44340); Yatsu Mt., $2000 \mathrm{~m}$ alt., (M) leg. VIII 1957 Inoue H., 7595 (NICH 38037); Nara Pref.: Oomine Mt., $900 \mathrm{~m}$ alt., (CT) leg. 03 VIII 1962 Tagawa M. \& N. Kitagawa, T1949 (NICH 70054); Nirgata Pref.: Renge-onsen to Tenguno-niwa, 1600-2200 m alt., (B) leg. 26 VII 1962 Kitagawa N., 6746 (NICH 70002); Shirouma Mt., 2200-2500 m alt., (B) leg. VIII 1957 Inoue H., 7481 (NICH 67416); Shinano Tsubakuro Mt. (B) leg. 19 VIII 1941 Hattori S., 1056 (NICH 15914); Yamagata Pref.: Chokai Mt., 1400 $\mathrm{m}$ alt., (B) leg. 06 VIII 1959 Mizutani M., s.n. (NICH 75497); Yamanashi Pref.: Fuji Mt., 1500-2400 m alt., (M) leg. 05 X 1961 Hulten E., s.n. (NICH 71811); Kaikoma Mt., 2500$2600 \mathrm{~m}$ alt., (B) leg. 26 VII 1958 Inoue H., 8133 (NICH 44423); Koma-ga-dake Stream $\left(35^{\circ} 44^{\prime} 44^{\prime \prime N} 138^{\circ} 14^{\prime} 02^{\prime \prime} \mathrm{E}\right)$, $2270 \mathrm{~m}$ alt. (B) 1 X $2015 \mathrm{VB}, \mathrm{j}-88-21-15$, j-88-60-15 (VBGI); Senjogadake Mt., $2300 \mathrm{~m}$ alt., (B) leg. 03 VIII 1967 Sakuma E., 11147 (NICH 95715); REPUBLIC OF KOREA: Jirisan $\left(35^{\circ} 20^{\prime} \mathrm{N} 127^{\circ} 44^{\prime} \mathrm{E}\right), 1600 \mathrm{~m}$ alt., (CT) leg. 14 VI 2009 $\mathrm{VB}$, kor-9-5-09 (VBGI); (35 $\left.20^{\prime} \mathrm{N} 127^{\circ} 44^{\prime} \mathrm{E}\right), 1800 \mathrm{~m}$ alt., (M) leg. 14 VI 2009 VB, kor-10-30-09 (VBGI); Seorak Mts. $\left(38^{\circ} 08^{\prime} \mathrm{N} 128^{\circ} 27^{\prime} \mathrm{E}\right), 1550 \mathrm{~m}$ alt., (M) leg. $12 \mathrm{~V} 2011 \mathrm{VB}$, kor-9-05-11 (VBGI); RUSSIA: AltaI Territory: Teletskoye Lake (51 $\left.{ }^{\circ} 42^{\prime} \mathrm{N} 87^{\circ} 25^{\prime} \mathrm{E}\right), 470 \mathrm{~m}$ alt., (B) leg. $01 \mathrm{VI} 1989$ Ignatov M.S., s.n. (KPABG 109200); BuRYATIA Republic: Khamar-Daban Mts., Anosovka River (B) leg. 05 VIII 2001 Konstantinova N.A., 16-3-01 (KPABG 102399); (B) leg. 04 VIII 2001 Konstantinova N.A., 10-2-01 (KPABG 102359); (B) leg. 04 VIII 2001 Konstantinova N.A., 10-2-01 (KPABG 102359);(B) leg. 04 VIII 2001 Konstantinova N.A., 13-2701 (KPABG 102388); (B) leg. 08 VIII 2001 Konstantinova N.A., 49-2a-01 (KPABG 102464); (B) leg. 11 VIII 2001 Konstantinova N.A., 100-01 (KPABG 104277); (B) leg. 07 VIII 1999 Bakalin V.A., s.n. (KPABG 109890); (B) leg. 08 VIII 1999 Bakalin V.A., s.n. (KPABG 109895); KAMCHATKA Territory: upper course of Icha River (C) leg. 14 IX 2002 Bakalin V.A., K-50-6-02 (KPABG 104102); KHABAROvsK Territory: De Kastri $\left(51^{\circ} 29^{\prime} \mathrm{N} 140^{\circ} 34^{\prime} \mathrm{E}\right), 147 \mathrm{~m}$ alt., (B) leg. 03 VIII 2011 Roenko E., 438/2 (VBGI); Tardoki-Yani Mts. $\left(48^{\circ} 50^{\prime} \mathrm{N} 138^{\circ} 05^{\prime} \mathrm{E}\right), 765 \mathrm{~m}$ alt., (B) leg. 20 VIII 2013 VB, kh-32-35-13 (VBGI); (48 $\left.48^{\prime} \mathrm{N} 138^{\circ} 06^{\prime} \mathrm{E}\right), 543 \mathrm{~m}$ alt., (B) leg. 28 VIII 2013 VB, kh-46-18-13 (VBGI); Primorsky Territory: Dalnegorsk, (B) leg. 21 VII 1976 Gambaryan S.K., s.n. (VBGI); Elomovsky Stream $\left(43^{\circ} 15^{\prime} \mathrm{N} 133^{\circ} 43^{\prime} \mathrm{E}\right)$, $500 \mathrm{~m}$ alt., (M) leg. 06 X $2006 \mathrm{VB}, \mathrm{p}-68-3 \mathrm{a}-06$ (VBGI); 


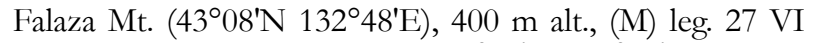
2012 VB, p-20-25-12 (VBGI); (430ㄱ'N 132 47'E), $550 \mathrm{~m}$ alt., (CT) leg. 25 VI $2012 \mathrm{VB}, \mathrm{p}-15-8-12$ (VBGI); $\left(43^{\circ} 07^{\prime} \mathrm{N}\right.$ 132 $\left.{ }^{\circ} 46^{\prime} \mathrm{E}\right), 400 \mathrm{~m}$ alt., (CT) leg. 18 IX $2012 \mathrm{VB}, \mathrm{p}-40-4-12$ (VBGI); Glubinnoye (B) leg. 18 VI 1991 Gambaryan S.K., s.n. (VBGI); Krasnoarmeysky District (B) leg. 16 VI 1991 Gambaryan S.K., s.n. (KPABG 104765); Lazo (M) leg. $20 \mathrm{~V}$ 1982 Bardunov L.V., Cherdantseva V.Ya., s.n. (VBGI); Lazovsky Pass $\left(43^{\circ} 30^{\prime} \mathrm{N} 133^{\circ} 35^{\prime} \mathrm{E}\right), 915 \mathrm{~m}$ alt., (B) leg. 22 IX 2011 VB, p-72-8-11 (VBGI); (M) leg. 22 IX 1974 Gambaryan S.K., s.n. (VBGI); (M) leg. 22 IX 1974 Bardunov L.V. \& V.Ya. Cherdantseva, s.n. (KPABG 104769); Milogradovka (B) leg. 26 VII 1980 Gambaryan S.K., s.n. (VBGI); Oblachnaya Mt., 900 m alt., (B) leg. 19 IX 1978 Gambaryan S.K., s.n. (VBGI); 1700 m alt., (B) leg. 19 IX 1978 Gambaryan S.K., s.n. (VBGI); Pravaya Sokolovka, $500 \mathrm{~m}$ alt., (B) leg. 22 IX 1976 Gambaryan S.K., s.n. (VBGI); 560 m alt., (B) leg. 21 IX 1976 Gambaryan S.K., s.n. (VBGI); Sikhote-Alin Reserve (B) leg. 02 VIII 1995 Gambaryan S.K., s.n. (VBGI); (M) leg. 24 IX 1997 Gambaryan S.K., s.n. (VBGI); (M) leg. 23 IX 1997 Gambaryan S.K., s.n. (VBGI); (B) leg. 30 IX 1997 Gambaryan S.K., s.n. (VBGI); (B) leg. 02 VIII 1995 Gambaryan S.K., s.n. (VBGI); Solnechnaya Pad $\left(43^{\circ} 27^{\prime} \mathrm{N}\right.$ 134¹3'E), $632 \mathrm{~m}$ alt., (M) leg. 21 IX 2012 VB, p-44-1-12 (VBGI); Ussurijsky Reserve' N (M) leg. 14 VII 1975 Gam-

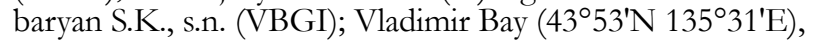
$25 \mathrm{~m}$ alt., (H) leg. 21 IX $2007 \mathrm{VB}, \mathrm{p}-83-26-07$ (VBGI); Sakhalin Province: Iturup Island $\left(45^{\circ} 05^{\prime} \mathrm{N} 148^{\circ} 00^{\prime} \mathrm{E}\right), 409$ $\mathrm{m}$ alt., (C + Sasa) leg. 15 IX 2005 VB, k-56-17-05 (VBGI); Nabilsky Range $\left(50^{\circ} 46^{\prime} \mathrm{N} 143^{\circ} 15^{\prime} \mathrm{E}\right), 500 \mathrm{~m}$ alt., (B) leg. 14 VIII 2006 VB, s-26-12-06 (VBGI); (5046'N 14315'E), 500 $\mathrm{m}$ alt., (B) leg. 14 VIII 2006 VB, s-26-16-06 (VBGI).

\section{Bazzania tricrenata}

AUSTRIA: Tirol: Weertal bei Schwaz, $1600 \mathrm{~m}$ alt., leg. 03 VIII 1903 Osterwald K. and Handel Mazzetti H.F., s.n. (NICH 229633); 600 m alt., leg. VII 1913 Loitlesberger K., s.n. (NICH 229632); GEORGIA: KaKHETI: Lagodekhi, 2100 m alt., (B) leg. 13 IX 1984 Tigishvili K., s.n. (VBGI); JAPAN: Gifu Pref.: Ontake Mt. leg. 27 VIII 1953 Fukuhara M., s.n. (NICH 233005); NAgano Pref.: Eboshi, 2300 $\mathrm{m}$ alt., (B) leg. 09 VIII 1952 Takaki N., 12395 (VBGI); Gaki, $2600 \mathrm{~m}$ alt., (B) leg. 13 VIII 1952 Takaki N., 12702 (VBGI); Ontake Mt., $2200 \mathrm{~m}$ alt., (B) leg. 25 VIII 1953 Fukuhara M., s.n. (NICH 232700); Senjoo Mt., 2600 m alt., (B) leg. 25 VII 1958 Inoue H., 8343 (NICH 44477); Shiomi Mt., 2400$2600 \mathrm{~m}$ alt., (B) leg. 03 VIII 1960 Inoue H., 8880 (NICH 48250); TOYAMA PREF. Tateyama Mt., 2600-2800 m alt., (B) leg. 15 VIII 1959 Inoue H., 8592 (NICH 46907); YAmagata Pref.: $1750 \mathrm{~m}$ alt., (B) leg. 26 VII 1984 Yuzawa Y., s.n. (NICH 193049); Yamanashi Pref.: 2500-2600 m alt., (B) leg. 26 VII 1958 Inoue H., 8131 (NICH 44428)

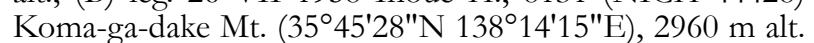
(C) 30 X 2015 VB, j-86-1-15 (VBGI); REPUBLIC OF KOREA: Jiri-san $\left(35^{\circ} 20^{\prime} \mathrm{N} 127^{\circ} 44^{\prime} \mathrm{E}\right), 1900 \mathrm{~m}$ alt., (M) leg. 15 VI 2009 VB, kor-11-10-09 (VBGI); (3520'N 1274'ㄹ), $1900 \mathrm{~m}$ alt., (B) leg. 15 VI 2009 VB, kor-11-9-09 (VBGI); Seorak Mt. leg. 15 X 2010 Choi S.S., 8687 (KPABG 115507); RUSSIA: BURYATIA Republic: Khamar-Daban Range (C) leg. 10 VIII 2001 Konstantinova N.A., 78-01 (VBGI); (B) leg. 04 VIII 1927 Smirnov V., s.n. (VBGI); leg. 05 VIII 2001 Konstantinova N.A., 27-4-01 (KPABG 102412); leg. 04 VIII 2001 Konstantinova N.A., 13-11-01 (KPABG 102412); (105²4'N 51³2'E), m alt., leg. 14 VIII 2001 Konstantinova N.A., 108-1-01 (KPABG 104295); leg. 07 VIII 2001 Konstantinova N.A., 42-3-01 (KPABG 102439); leg. 09 VIII 2001 Konstantinova N.A., 57-1-01 (KPABG 102478); Goltsovsky Golets (Snezhnaya River) (B) leg. 10 VIII 1999 Bakalin V.A., s.n. (KPABG 109915); КАмснAтKA Territory: upper Icha River course $\left(55^{\circ} 40^{\prime} \mathrm{N} 157^{\circ} 40^{\prime} \mathrm{E}\right)$, 700 m alt., (B) leg. 14 IX 2002 Bakalin V.A., K-50-18-02
(KPABG 104111); Ploskij Khrebet $\left(52^{\circ} 50^{\prime} \mathrm{N} 157^{\circ} 40^{\prime} \mathrm{E}\right)$, $600 \mathrm{~m}$ alt., (C) leg. 08 VI 2003 Bakalin V.A., K-23-2-03 (KPABG 105031); KaRachaevo-Cherkessiya Republic: Teberda $\left(43^{\circ} 28^{\prime} \mathrm{N} 41^{\circ} 41^{\prime} \mathrm{E}\right), 1760 \mathrm{~m}$ alt., (CT) leg. $21 \mathrm{IX}$ 2005 Konstantinova N.A., s.n. (VBGI); KHabarovsk TerRITORY: Ayan (H) leg. 20 VIII 1989 Cherdantseva V.Ya., s.n. (VBGI); Dusse-Alin Range $\left(52^{\circ} 05^{\prime} \mathrm{N} 135^{\circ} 01^{\prime} \mathrm{E}\right), 1600 \mathrm{~m}$ alt., (C) leg. 11 VIII 1997 Ignatov M.S., s.n. (KPABG 107338); Tardoki-Yani Mts. (48 $\left.{ }^{\circ} 54^{\prime} \mathrm{N} 138^{\circ} 01^{\prime} \mathrm{E}\right), 1825 \mathrm{~m}$ alt., (A) leg. 25 VIII 2013 VB, kh-42-1-13 (VBGI); (4852'N 13804'E), (B) leg. 28 VIII 2012 Barkalov V.Yu., s.n. (VBGI); $\left(48^{\circ} 54^{\prime} \mathrm{N}\right.$ $\left.138^{\circ} 00^{\prime} \mathrm{E}\right), 1884 \mathrm{~m}$ alt., (C) leg. 25 VIII $2013 \mathrm{VB}$, kh-4118-13 (VBGI); (48 $\left.54^{\prime} \mathrm{N} 138^{\circ} 03^{\prime} \mathrm{E}\right), 2048 \mathrm{~m}$ alt., (A) leg. 26 VIII 2013 VB, kh-43-4-13 (VBGI); (48 53'N 138 03'E), 1940 m alt., (A) leg. 24 VIII 2013 VB, kh-40-14-13 (VBGI); Perm' Province: Basegi Reserve (58 $\left.45^{\prime} \mathrm{N} 58^{\circ} 25^{\prime} \mathrm{E}\right), 514$ $\mathrm{m}$ alt., leg. 07 IX 2004 Konstantinova N.A., K-387-1a-04 (KPABG 108409); Primorsky Territory: Puzikov Pass $\left(43^{\circ} 39^{\prime} \mathrm{N} 133^{\circ} 35^{\prime} \mathrm{E}\right), 1250 \mathrm{~m}$ alt., (B) leg. $14 \mathrm{IX} 2014 \mathrm{VB}$,

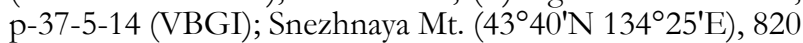
$\mathrm{m}$ alt., (M) leg. 15 IX $2014 \mathrm{VB}, \mathrm{p}-39-2-14$ (VBGI), $\left(43^{\circ} 38^{\prime} \mathrm{N}\right.$ 134²1'E), $721 \mathrm{~m}$ alt., (B) leg. 19 IX $2007 \mathrm{VB}, \mathrm{p}-79-6-07$

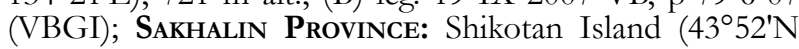
$\left.146^{\circ} 51^{\prime} \mathrm{E}\right), 400 \mathrm{~m}$ alt., (H) leg. 08 IX $2007 \mathrm{VB}, \mathrm{k}-66-7-07$ (VBGI); SLOVAKIA: Rohace Mts., $1200 \mathrm{~m}$ alt., (C) leg. 21 V 1984 Soldan Z., s.n. (KPABG s.n.); SWITZERLAND: Bern Kanton: Kandersteg, $900 \mathrm{~m}$ alt., leg. 21 X 1986 Ruegsegger S., s.n. (KPABG s.n.); U.S.A.: Alaska: Atka Island, $250 \mathrm{~m}$ alt., (H) leg. 26 VII 1990 Smith D.K. \& P.G. Davison, 11043E (VBGI).

\section{Bazzania trilobata}

GEORGIA: AdJARA: $\left(41^{\circ} 41^{\prime} \mathrm{N} 41^{\circ} 53^{\prime} \mathrm{E}\right), 400 \mathrm{~m}$ alt., (CT) leg. 12 V 2013 VB, g-12-52-13 (VBGI); JAPAN: EHIME Pref.: Higashiakaishi Mt., $1500 \mathrm{~m}$ alt., (CT) leg. 09 VIII 1950 Yamanaka T., 190 (NICH 237419); FuKushima Pref.: Gamo Mt. leg. 14 VIII 1970 Baba Y., 10007 (NICH 115627); Gifu Pref.: Ontake Mt. leg. 27 VIII 1953 Fukuhara M., s.n. (NICH 233029); HokkaIdo Pref.: Jozankei, 750-900 m alt., (M) leg. 04 VIII 1971 Iwatsuki Z., 1081 (NICH 121896); Nakano-onsen, $720 \mathrm{~m}$ alt., (M) leg. 19 VII 1981 Takida K., s.n. (NICH 182506); Rishiri, $10 \mathrm{~m}$ alt., (B) leg. 17 VIII 1971 Iwatsuki Z., 1944 (NICH 122028); KoCHI Pref.: Kajigamori Mt., 900-1000 m alt., (CT) leg. 01 V 1949 Yamanaka T., 359 (NICH 74468); Nagano Pref.: Yatsu Mt., $2000 \mathrm{~m}$ alt., (B) leg. VIII 1957 Inoue H., 7566 (NICH 38009); Yamanashi Pref.: Fuji Mt. leg. 25 VII 1959 Mizutani M., 681 (NICH 43612); REPUBLIC OF KOREA: Seorak Mts. $\left(38^{\circ} 08^{\prime} \mathrm{N} 128^{\circ} 26^{\prime} \mathrm{E}\right), 800 \mathrm{~m}$ alt., (CT) leg. 11 V 2011 VB, kor-5-30-11 (VBGI); RUSSIA: Khabarovsk Territory: Bolshekhekhtsirsky Reserve (B) leg. 18 IX 1982 Gambaryan S.K., s.n. (VBGI); De Kastri $\left(51^{\circ} 39^{\prime} \mathrm{N} 140^{\circ} 55^{\prime} \mathrm{E}\right), 248 \mathrm{~m}$ alt., (B) leg. 05 VIII 2011 Roenko E., 22 (VBGI); (51 $\left.25^{\prime} \mathrm{N} 140^{\circ} 14^{\prime} \mathrm{E}\right), 64 \mathrm{~m}$ alt., (B) leg. 04 VIII 2011 Roenko E., 450 (VBGI); (512ㄴ'N 140 14'E), $56 \mathrm{~m}$ alt., (B) leg. 04 VIII 2011 Roenko E., 448 (VBGI); $\left(51^{\circ} 25^{\prime} \mathrm{N} 140^{\circ} 14^{\prime} \mathrm{E}\right), 115 \mathrm{~m}$ alt., (B) leg. 04 VIII 2011 Roenko E., 449 (VBGI); Eldigin (B) leg. 25 IX 1939 Nikolayev A., s.n. (VBGI); Komsomolsky Reserve (B) leg. 01 IX 1987 Gambaryan S.K., s.n. (VBGI); (B) leg. 20 VIII 1986 Gambaryan S.K., s.n. (VBGI); Okhotsk $\left(59^{\circ} 26^{\prime} \mathrm{N} 143^{\circ} 30^{\prime} \mathrm{E}\right)$, $124 \mathrm{~m}$ alt., (Hem) leg. 19 VII $2008 \mathrm{VB}$, kh-19-3-08 (VBGI); $\left(59^{\circ} 26^{\prime} \mathrm{N} 143^{\circ} 30^{\prime} \mathrm{E}\right), 124 \mathrm{~m}$ alt., (Hem) leg. 26 VII $2008 \mathrm{VB}$, kh-41-2-08 (VBGI); Solnechnyj (5043'N 136²4'E), $980 \mathrm{~m}$ alt., (B) leg. $29 \mathrm{~V} 2007 \mathrm{VB}, \mathrm{kh}-5-41-07$ (VBGI); TardokiYani Mts. (48 $\left.48^{\prime} \mathrm{N} 138^{\circ} 06^{\prime} \mathrm{E}\right), 543 \mathrm{~m}$ alt., (M) leg. $28 \mathrm{VIII}$ 2013 VB, kh-46-20-13 (VBGI); (4850'N 13805'E), 765 m alt., (B) leg. 20 VIII 2013 VB, kh-32-2-13 (VBGI); Yakatyn River (B) leg. 20 VII 1961 Khokhlova I.K., s.n. (VBGI); Magadan Province: Magadan City $\left(59^{\circ} 31^{\prime} \mathrm{N} 150^{\circ} 49^{\prime} \mathrm{E}\right)$, $350 \mathrm{~m}$ alt., (C) leg. 11 VIII $2011 \mathrm{VB}$, mag-61-13-11 (VBGI); 
(59 $\left.31^{\circ} \mathrm{N} 150^{\circ} 40^{\prime} \mathrm{E}\right), 10 \mathrm{~m}$ alt., (C) leg. $13 \mathrm{VIII} 2011 \mathrm{VB}$ mag-28-37-13 (VBGI); Primorsky Territory: Falaza Mt. $\left(43^{\circ} 06^{\prime} \mathrm{N} 132^{\circ} 47^{\prime} \mathrm{E}\right), 1000 \mathrm{~m}$ alt., (B) leg. 26 VI $2012 \mathrm{VB}$,

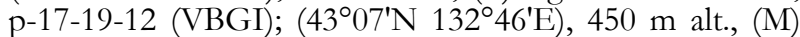

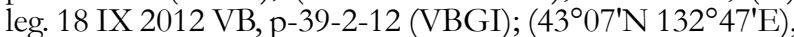
$800 \mathrm{~m}$ alt., (B) leg. 26 VI 2012 VB, p-16-9-12 (VBGI); Pidan Mt. $\left(43^{\circ} 05^{\prime} \mathrm{N} 132^{\circ} 42^{\prime} \mathrm{E}\right), 1046 \mathrm{~m}$ alt., (B) leg. $07 \mathrm{X} 2008 \mathrm{VB}$ p-59-2-08 (VBGI); (430' $\left.\mathrm{N} 132^{\circ} 42^{\prime} \mathrm{E}\right), 413 \mathrm{~m}$ alt., (M) leg. 09 X $2005 \mathrm{VB}, \mathrm{p}-72-13-05$ (VBGI); (43ํ6'N 132 $\left.42^{\prime} \mathrm{E}\right)$, $700 \mathrm{~m}$ alt., (B) leg. 06 IX $2010 \mathrm{VB}, \mathrm{p}-39-6-10$ (VBGI); Puzikov Pass $\left(43^{\circ} 39^{\prime} \mathrm{N} 133^{\circ} 35^{\prime} \mathrm{E}\right), 1250 \mathrm{~m}$ alt., (B) leg. 14 IX 2014 VB, p-37-25-14 (VBGI); Sikhote-Alin Reserve (B) leg. V 1979 Flyagina I.A., s.n. (VBGI); (M) leg. 13 VIII 1976 Doronina Yu.A., s.n. (VBGI); (B) leg. 01 IX 1957 Shemetova N.S., s.n. (VBGI); (M) leg. 23 IX 1997 Gambaryan S.K., s.n. (VBGI); Snezhnaya Mt. $\left(43^{\circ} 38^{\prime} \mathrm{N} 134^{\circ} 21^{\prime} \mathrm{E}\right), 721$ $\mathrm{m}$ alt., (B) leg. 19 IX $2007 \mathrm{VB}, \mathrm{p}-79-5-07$ (VBGI); (434' $\mathrm{N}$ 134²6'E), $1200 \mathrm{~m}$ alt., (C) leg. 17 IX $2007 \mathrm{VB}, \mathrm{p}-74-1-07$ (VBGI); $\left(43^{\circ} 36^{\prime} \mathrm{N} 134^{\circ} 13^{\prime} \mathrm{E}\right), 600 \mathrm{~m}$ alt., (M) leg. $16 \mathrm{IX}$ 2007 VB, p-70-8-07 (VBGI); (4339'45"N 134²4'32"E), $820 \mathrm{~m}$ alt. (M) 15 IX $2014 \mathrm{VB}, \mathrm{p}-39-14-14$ (VBGI); SAKHALIN Province: Firsovo (B) leg. 22 VIII 2008 Barkalov V.Yu., s.n. (VBGI); Iturup Island $\left(44^{\circ} 49^{\prime} \mathrm{N} 147^{\circ} 21^{\prime} \mathrm{E}\right), 50$ $\mathrm{m}$ alt., (B) leg. 20 VIII 2007 VB, k-35-4-07 (VBGI); Korsakov $\left(46^{\circ} 34^{\prime} \mathrm{N} 143^{\circ} 15^{\prime} \mathrm{E}\right), 39 \mathrm{~m}$ alt., (B) leg. 16 IX 2009 VB, s-64-1-09 (VBGI); (46 $\left.27^{\circ} \mathrm{N} 143^{\circ} 23^{\prime} \mathrm{E}\right), 85 \mathrm{~m}$ alt., (B) leg. 16 IX 2009 VB, s-65-6-09 (VBGI); Kunashir Island $\left(43^{\circ} 52^{\prime} \mathrm{N} 145^{\circ} 30^{\prime} \mathrm{E}\right), 180 \mathrm{~m}$ alt., (B) leg. $04 \mathrm{IX} 2006 \mathrm{VB}$,

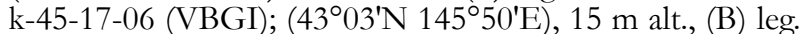
09 IX $2006 \mathrm{VB}, \mathrm{k}-50-9-06$ (VBGI); (44ำ $\left.15^{\prime} \mathrm{N} 146^{\circ} 06^{\prime} \mathrm{E}\right)$, $27 \mathrm{~m}$ alt., (B) leg. 07 IX $2006 \mathrm{VB}, \mathrm{k}-63-30-06$ (VBGI); (44ำ $\left.16^{\prime} \mathrm{N} 146^{\circ} 06^{\prime} \mathrm{E}\right), 21 \mathrm{~m}$ alt., (B) leg. 17 IX $2006 \mathrm{VB}, \mathrm{k}-61-$ 8-06 (VBGI); $\left(43^{\circ} 03^{\prime} \mathrm{N} 145^{\circ} 50^{\prime} \mathrm{E}\right), 15 \mathrm{~m}$ alt., (B) leg. $09 \mathrm{IX}$ 2006 VB, k-50-14-06 (VBGI); Mereya $\left(46^{\circ} 38^{\prime} \mathrm{N} 142^{\circ} 54^{\prime} \mathrm{E}\right)$, $6 \mathrm{~m}$ alt., (B) leg. 11 VIII 2006 VB, s-24-2-06 (VBGI); Nabilsky Range $\left(50^{\circ} 46^{\prime} \mathrm{N} 143^{\circ} 17^{\prime} \mathrm{E}\right), 801 \mathrm{~m}$ alt., (B) leg. $16 \mathrm{VIII}$ $2006 \mathrm{VB}, \mathrm{s}-29-15-06$ (VBGI); (5046'N 14315'E), $500 \mathrm{~m}$ alt., (B) leg. 14 VIII 2006 VB, s-26-8-06 (VBGI); Nevelsk $\left(46^{\circ} 43^{\prime} \mathrm{N} 141^{\circ} 58^{\prime} \mathrm{E}\right), 31 \mathrm{~m}$ alt., (M) leg. $17 \mathrm{IX} 2009 \mathrm{VB}$, s-69-8-09 (VBGI); Nikolayevka (534ㅇ'N 14237'E), $35 \mathrm{~m}$ alt., (B) leg. 26 VIII 2009 VB, s-36-1-09 (VBGI); Schmidt Peninsula $\left(54^{\circ} 03^{\prime} \mathrm{N} 142^{\circ} 58^{\prime} \mathrm{E}\right), 110 \mathrm{~m}$ alt., (B) leg. $30 \mathrm{VIII}$ 2009 VB, s-43-7-09 (VBGI); Shikotan Island $\left(43^{\circ} 48^{\prime} \mathrm{N}\right.$ 1463'ㄹ), $340 \mathrm{~m}$ alt., (B) leg. 27 VIII $2007 \mathrm{VB}, \mathrm{k}-47-27-07$ (VBGI); (43⒋ $\left.48^{\prime} \mathrm{N} 146^{\circ} 36^{\prime} \mathrm{E}\right), 110 \mathrm{~m}$ alt., (B) leg. $30 \mathrm{VIII}$ $2007 \mathrm{VB}, \mathrm{k}-50-48-07$ (VBGI); $\left(43^{\circ} 45^{\prime} \mathrm{N} 146^{\circ} 43^{\prime} \mathrm{E}\right), 40 \mathrm{~m}$ alt., (B) leg. 03 IX 2007 VB, k-61-5-07 (VBGI); (434ㅇ' $\mathrm{N}$ $146^{\circ} 43^{\prime} \mathrm{E}$ ), $17 \mathrm{~m}$ alt., (H) leg. 24 VIII $2007 \mathrm{VB}, \mathrm{k}-39-2-07$ (VBGI); (434ㅇ' $\left.146^{\circ} 39^{\prime} \mathrm{E}\right), 120 \mathrm{~m}$ alt., (B) leg. 28082007 VB, k-49-33-07 (VBGI); Vaida (49 $\left.53^{\prime} \mathrm{N} 143^{\circ} 27^{\prime} \mathrm{E}\right), 425 \mathrm{~m}$ alt., (B) leg. 21 VIII 2006 VB, s-35-3-06 (VBGI); Wladimiroff (B) leg. 09 X 1907 Faurie U., 1 (KYO); (B) leg. 06 1908 Faurie U., 111 (KYO); (B) leg. 09 X 1907 Faurie U., s.n. (KYO); Yuzhno-Sakhalinsk (46 $\left.58^{\circ} \mathrm{N} 142^{\circ} 47^{\prime} \mathrm{E}\right), 240 \mathrm{~m}$ alt., (B) leg. 31 VIII 2005 VB, s-35-3-05 (VBGI); Zhdanko

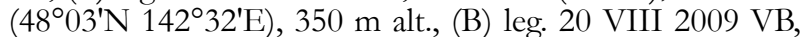
s-26-1-09 (VBGI); U.S.A.: MichigAN: Cheboygan County (CT) leg. 29 VI 1991 Bourell M., 4003 (VBGI); MissourI: Saint Genevieve County $\left(37^{\circ} 53^{\prime} \mathrm{N} 90^{\circ} 18^{\prime} \mathrm{W}\right), 300 \mathrm{~m}$ alt. (CT) leg. 26 X 2014 Bakalin V. \& J. Brinda, us-41-48-14 (VBGI); North Carolina: Macon County, $1150 \mathrm{~m}$ alt., (CT) leg. 09 VI 1984 Gowan G.C., 1255 (VBGI); TenNESSEE: Sevier County, 2000 m alt., (B) leg. 13 VII 1991 Smith D.K. \& P.G. Davison, s.n. (VBGI).

\section{ACKNOWLEDGEMENTS}

I cordially thank of the curators of $\mathrm{G}, \mathrm{KPABG}, \mathrm{NICH}$ and STR for the permission to work in those herbaria, which provided needed facilities. The line drawings for the present account were kindly compiled by Mr. M.A. Bakalin to whom author is sincerely grateful. The work was partially supported by the grant from the Russian Foundation for Basic Researches (15-34-20101).

\section{LITERATURE CITED}

Bakalin, V.A. 2010. Distribution of bryophytes in the Russian Far East. Part. I. Hepatics. Izd-vo DVFU, Vladivostok, 175 pp.

Bakalin, V.A. 2014. Caucasian-Manchurian relationships in the hepatic flora. Arctoa 23: 150-163.

Bakalin, V.A. \& T. Katagiri 2014. The historical collection of liverworts from Sakhalin by Urbian Faurie (18461915) in herbarium of Kyoto. Arctoa 23: 29-32.

Crandall-Stotler, B., R.E. Stotler \& D.G. Long 2009. Phylogeny and classification of the Marchantiophyta. Edinburgh Journal of Botany 66(1):155-198.

Damsholt, K. 2004. Illustrated Flora of Nordic Liverworts and Hornworts. Nord. Bryol. Soc., Lund, 840 pp.

Frey, W. 2009. Syllabus of Plant Families. Part. 3. Science Publishers, Stuttgart, 419 pp.

Furuki, T. 2015. Taxonomical study of Bazzania fissifolia var. subsimplex, a new synonym of Bazzania imbricata (Lepidoziaceae, Marchantiophyta) from Japan. Hikobia 17:17-20.

Hattori, S. \& M. Mizutani 1958. A revision of the Japanese species of the family Lepidoziaceae. The Journal of the Hattori Botanical Laboratory 33:76-118.

Konstantinova, N.A. \& V.A. Bakalin with contributions on regional floras from E.N. Andrejeva, A.G. Bezgodov, E.A. Borovichev, M.V. Dulin, Yu.S. Mamontov 2009. Checklist of liverworts (Marchantiophyta) of Russia. Arctoa 18: 1-64.

Paton, J.A. 1999. The liverwort Flora of the British Isles. Harley Books, Colchester, 626 pp.

Pocs, T. 1969. A short survey of the Bazzania of North Viet-Nam. The Journal of the Hattori Botanical Laboratory 32: 79-94.

Popov, M.G. 1983. Phylogeny, florogenetics, systematics. Selected works. Vol. 1. Naukova Dumka, Kiyev, 280 pp. [Попов М.Г. 1983. Филогения, флорогенетика, систематика. Избранные труды. Том 1. Киев: Наукова Аумка. 280 c.].

Schuster, R.M. 1969. The Hepaticae and Anthocerotae of North America East of Hundredth Meridian. Columbia University press, New York, 1062 pp.

Yamada, K. \& Z. Iwatsuki. 2006. Catalog of the hepatics of Japan. The Journal of the Hattori Botanical Laboratory 99: $1-106$.

Zerov, D.K. 1962. The family Lepidoziaceae in the Soviet Far East. Ukrainsky Botanicheskij Zhurnal 23(3):86-95 (in Ukrainian). [Зеров А.К. 1962. Родина Родина лепідозіэві (Lepidoziaceae) у фморі радянського Аалекого Сходу // Український ботанічний журнал. Т. 23, № 3. С. 86-95]. 